\title{
Environment and food safety: a novel integrative review
}

\author{
Shanxue Jiang ${ }^{1,2,3} \cdot$ Fang Wang $^{1,2,3} \cdot{\text { Qirun } \mathrm{Li}^{1} \cdot \text { Haishu Sun }}^{4} \cdot$ Huijiao Wang ${ }^{5} \cdot$ Zhiliang Yao $^{1,2,3}$ (D)
}

Received: 3 June 2021 / Accepted: 16 August 2021 / Published online: 25 August 2021

(C) The Author(s), under exclusive licence to Springer-Verlag GmbH Germany, part of Springer Nature 2021

\begin{abstract}
Environment protection and food safety are two critical issues in the world. In this review, a novel approach which integrates statistical study and subjective discussion was adopted to review recent advances on environment and food safety. Firstly, a scientometric-based statistical study was conducted based on 4904 publications collected from the Web of Science Core Collection database. It was found that the research on environment and food safety was growing steadily from 2001 to 2020 . Interestingly, the statistical analysis of most-cited papers, titles, abstracts, keywords, and research areas revealed that the research on environment and food safety was diverse and multidisciplinary. In addition to the scientometric study, strategies to protect environment and ensure food safety were critically discussed, followed by a discussion on the emerging research topics, including emerging contaminates (e.g., microplastics), rapid detection of contaminants (e.g., biosensors), and environment friendly food packaging materials (e.g., biodegradable polymers). Finally, current challenges and future research directions were proposed.
\end{abstract}

Keywords Food safety $\cdot$ Environmental pollution $\cdot$ Food packaging $\cdot$ Biodegradable polymers $\cdot$ Biosensors $\cdot$ Microplastics $\cdot$ Soil pollution

\section{Introduction}

Environment and food safety have been two important topics in the world (Zhang et al. 2015; Bilal and Iqbal 2020; Liu et al. 2020b; Song et al. 2020; Ye et al. 2020; Qin et al. 2021). Human activities have posed great threats on environment and food safety. For example, due to the intensive use of

Responsible Editor: Lotfi Aleya

Zhiliang Yao

yaozhl@th.btbu.edu.cn

1 School of Ecology and Environment, Beijing Technology and Business University, Beijing 100048, China

2 State Environmental Protection Key Laboratory of Food Chain Pollution Control, Beijing Technology and Business University, Beijing 100048, China

3 Key Laboratory of Cleaner Production and Integrated Resource Utilization of China National Light Industry, Beijing Technology and Business University, Beijing 100048, China

4 Department of Environmental Engineering, University of Science and Technology Beijing, Beijing 100083, China

5 School of Chemical and Environmental Engineering, China University of Mining and Technology (Beijing), Beijing 100083, China disposable masks which are mainly made of nonbiodegradable polymers, massive amount of waste is produced. In fact, environment and food safety are closely intercorrelated (He et al. 2016; Sagbara et al. 2020). As shown in Figure 1, on the one hand, food safety is strongly affected by environment ( $\mathrm{Lu}$ et al. 2015). Contaminants from polluted soil, water, and air could migrate into crops, vegetables, fish, animals, and so on (Lu et al. 2015; Sun et al. 2017; Li et al. 2020a). On the other hand, in order to ensure food safety and quality, various processing procedures are carried out, which increase the burden on the environment and even cause environmental pollution (Yao et al. 2020). For example, food processing industry produces a huge amount of wastewater $(\mathrm{Li}$ et al. 2019; Ahmad et al. 2020; Akansha et al. 2020; Boguniewicz-Zablocka et al. 2020). If the wastewater is discharged into rivers directly, the rivers will be polluted. As food industry wastewater typically contains high concentrations of organic matters, eutrophication can easily take place (Feng et al. 2021; Jiang et al. 2021). In addition, food packaging materials are widely used as food containers and to preserve food from decay (Vitale et al. 2018; Wohner et al. 2020; Zeng et al. 2021). When the food is consumed, a mass of packaging waste is produced, which will cause environmental problems if not disposed properly (Poyatos- 
Fig. 1 Illustration of the relationship between environment and food safety and their impacts on human health

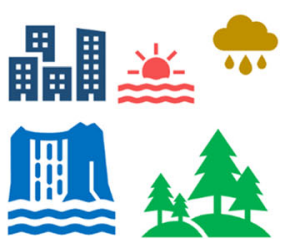

Environmental pollution can affect food safety

Food waste can cause environmental pollution

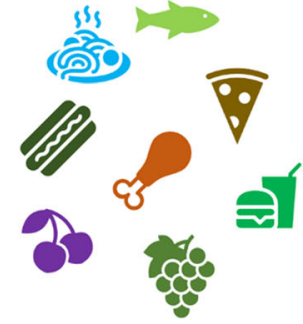

Food safety

Environment

Human health is affected
by environment

ก้

Human health

Racionero et al. 2018; Bala et al. 2020; Brennan et al. 2020; Liu et al. 2020a). However, plastics, as one of the most commonly used packaging materials, cannot be disposed easily and can exist in the environment for hundreds of years (Barnes 2019; Chen et al. 2021b; Mulakkal et al. 2021; Patrício Silva et al. 2021).

Environment and food safety have strong impacts on human health (Fung et al. 2018; Gallo et al. 2020). Many studies are conducted to investigate the migration of contaminants from the environment to food, and finally to human beings. For example, it is reported that heavy metals in the aquatic environment can migrate into fishes via bioaccumulation and bioconcentration (Baki et al. 2018; Korkmaz et al. 2019; Arisekar et al. 2020). When these polluted fishes are consumed, the heavy metals will migrate into human bodies (Saha et al. 2016; Gholamhosseini et al. 2021). Although the concentrations of heavy metals in the fishes are usually below the maximum allowed level (Velusamy et al. 2014; Safiur Rahman et al. 2019), the fact that humans are at the top of the food chain cannot be ignored. In other words, as there are various food sources for human beings, the heavy metals in our bodies could accumulate and finally reach a level that causes serious health risks, such as cancer (Badamasi et al. 2019; Yu et al. 2020a). In addition to the common types of contaminants (e.g., heavy metals, pesticides, pathogen, particulate matter), there are also some emerging types of contaminants (e.g., microplastics, personal care products, pharmaceuticals), and more efforts are needed to study their effects on human health (Aghilinasrollahabadi et al. 2020; Li et al. 2020b; Zhang et al. 2020).

Given the importance of environment and food safety, it is not surprising that a lot of related studies have been published, including many review studies. For example, Qin et al (2021) reviewed the effects of heavy metals in soil on food safety in China and discussed the sources (e.g., pesticides, fertilizers, vehicle emissions, coal combustion, sewage irrigation, mining) and remediation strategies (e.g., soil amendments, phytoremediation, foliar sprays). Suhani et al. (Suhani et al. 2021) reviewed the effects of cadmium pollution on food safety and human health with a focus on the mechanisms (e.g., cellular or molecular alterations). Deshwal et al. (Deshwal and Panjagari 2020) reviewed the effects of metal-based packaging materials on food safety and health issues (e.g., bisphenol A migration, metal migration, dissolution, blackening, and corrosion). Sun et al. (Sun et al. 2017) reviewed the relationship between air pollution and food security with a focus on the food system (e.g., the effect of agricultural policy on food security). However, most of these review studies only focus on certain subfields (Ayelign and De Saeger 2020; Endersen and Coffey 2020; Imathiu 2020; Nelis et al. 2020; Singh et al. 2020a). In addition, most of these reviews are based solely on the subjective experiences of the researchers in the related fields. In the age of big data, it is necessary to give a timely update on the research of environment and food safety through objective data analysis. The scientometric-based statistical method provides a powerful tool to disclose research trends and progress on certain research areas through data analysis of published documents. However, although there are already quite a few scientometric studies on other research areas (Jiang et al. 2018; Li et al. 2018; Kamali et al. 2020; Khalaj et al. 2020; Zakka et al. 2021; Zeb et al. 2021; Ni et al. 2021), the scientometric studies on environment and food safety are very limited. Therefore, the aim of this study is to provide an integrative review on environment and food safety via objective statistical analysis coupled with subjective review on strategies to protect the environment and ensure food safety, followed by a discussion on emerging research topics.

\section{A scientometric review}

As shown in Figure 2, during the past 20 years, there were nearly 5000 publications on the topic of environment and food 
Fig. 2 Number of publications per year and cumulative number of publications from 2001 to 2020

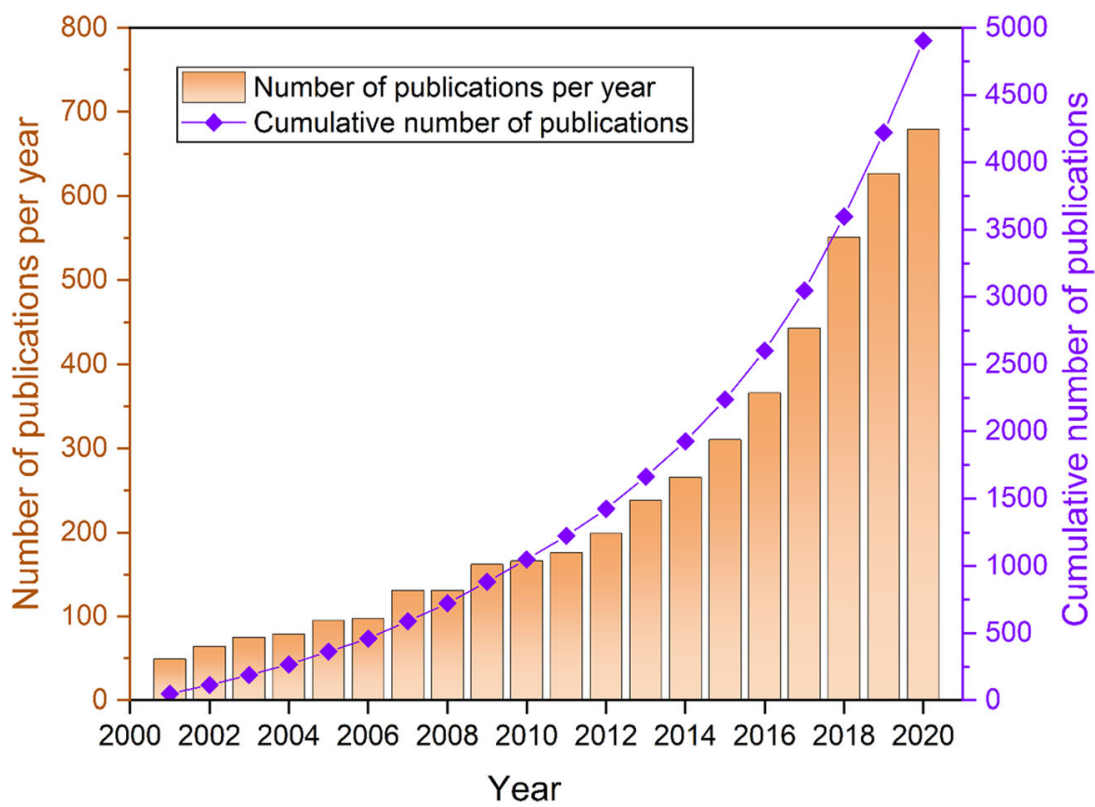

safety (detailed method was provided in the Supplementary Information). From 2001 to 2020, there was a steady increase in publications every year. Meanwhile, it was indicated that the increase in research output slowed down in 2020, possibly due to the terrible coronavirus pandemic which suspended researchers' lab work. In terms of document types, the 4904 publications were categorized into 10 types, where research article, review, and proceedings paper were the top three, accounting for $73.23 \%, 16.54 \%$, and $13.09 \%$ of the total publications, respectively (Supplementary Table 1). In terms of languages, most of the documents were published in English, accounting for $96.76 \%$ of the total publications (Supplementary Table 2). The following languages were German $(0.67 \%)$, Chinese $(0.57 \%)$, Portuguese $(0.43 \%)$, Spanish $(0.41 \%)$, French $(0.39 \%)$, etc. The language analysis revealed that a SCIE journal is not necessarily an English journal. For example, among the journals included in the data, the SCIE journal Berliner und Munchener Tierarztliche Wochenschrift publishes research results in German, and the SCIE journal Progress in Chemistry publishes research results in Chinese. To be available to researchers from all over the world, an English version of the titles, keywords, and abstracts of these publications are also provided. However, as the main text is not written in English, the impact of these publications is usually limited to the local research community, i.e., the papers written in German is normally only read by German researchers while the papers written in Chinese is normally only read by Chinese researchers.

In terms of journals, about 165 journals published at least 5 papers, and the total papers published in these journals accounted to about half of the total publications (more details are provided in supplementary data). Furthermore, as shown in Figure 3, the total papers published in the top 20 most publishing journals accounted to about one-fourth of the total publications. These results revealed that the research on environment and food safety is of broad interest.

In terms of publishing countries/regions, more than 100 countries/regions contributed to these publications (more details are provided in supplementary data). Especially, more than 50 countries/regions contributed at least 20 publications to the research on environment and food safety during the past 20 years. These results again revealed that the research on environment and food safety is of global interest. As shown in Figure 4, in terms of research output, the USA and China were leading the research on environment and food safety. Specifically, among the countries/regions, the USA was undoubtedly the most publishing country, which accounted for nearly one-fourth of the total publications. The runner-up was China, which contributed to around $15 \%$ of the total publications. However, it does not mean that the USA and China have contributed to around $40 \%$ of the total publications because many papers are published as a result of collaborations among several countries.

Generally, over 400 research institutes had contributed at least 5 publications to the research on environment and food safety, and nearly 50 research institutes published at least 20 papers during the past 20 years (more details are provided in supplementary data). The top 20 most publishing research institutes were summarized in Table 1. Chinese Academy of Sciences (CAS), which ranked the first place based on number of publications, is the largest cluster of research institutes in China. The research conducted by CAS is quite diverse and multidisciplinary. Especially, the research on environment and food safety is loosely conducted by different CAS research institutes, including but are not limited to Research Center for Eco-Environmental Sciences (RCEES), Institute 
Fig. 3 Number of publications and cumulative percentage of the top 20 most publishing journals

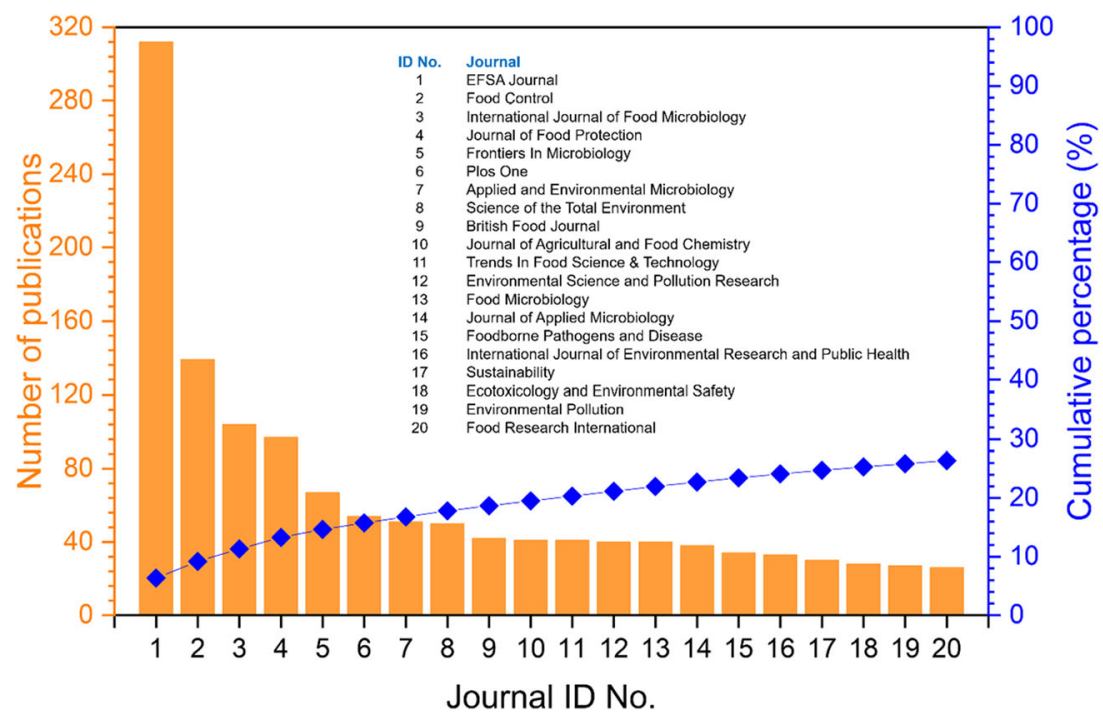

of Urban Environment, and Institute of Soil Science. For example, researchers from RCEES found that water pollution and soil pollution had serious effect on food safety and human health (Lu et al. 2015). The next one, USDA ARS, short for United States Department of Agriculture Agricultural Research Service, is a leading research institute in the USA focusing on food safety and human health from the aspect of agriculture. Similarly, US FDA is short for United States Food and Drug Administration and is exclusively focusing on food and drug-related research so as to protect public health. INRA, short for French National Institute of Agronomic Research, is a very famous research institute in Europe focusing on agricultural research. Similarly, Istituto Superiore di Sanità is a leading research institute in Italy focusing on public health. In addition to the above 5 research institutes, the remaining 15 research institutes are all universities, and their research on environment and food safety is mainly conducted by the related departments or research centers of the universities. For examples, the Department of Food Technology, Food Safety and Health at Ghent University (located in Belgium) is renowned for its state-of-the-art research on food technology, food microbiology, food chemistry, food safety, etc. Similarly, Wageningen University (located in Netherlands) has a research institute named Wageningen Food Safety Research. Another two European universities were both from Denmark, namely University of Copenhagen and Technical University of Denmark. The Department of Food Science at University of Copenhagen and the National Food Institute at Technical University of Denmark are mainly responsible for food-related research. Besides, there were also two universities from China (i.e., China Agricultural University and Zhejiang University) and one university from Canada (i.e., University of Guelph). The remaining 8 universities all came from the USA, accounting for over half of the universities in the top 20 most publishing research institutes, which corresponded well with the above countries/regions analysis.
Fig. 4 Number of publications and corresponding percentage of the top 20 most publishing countries/regions

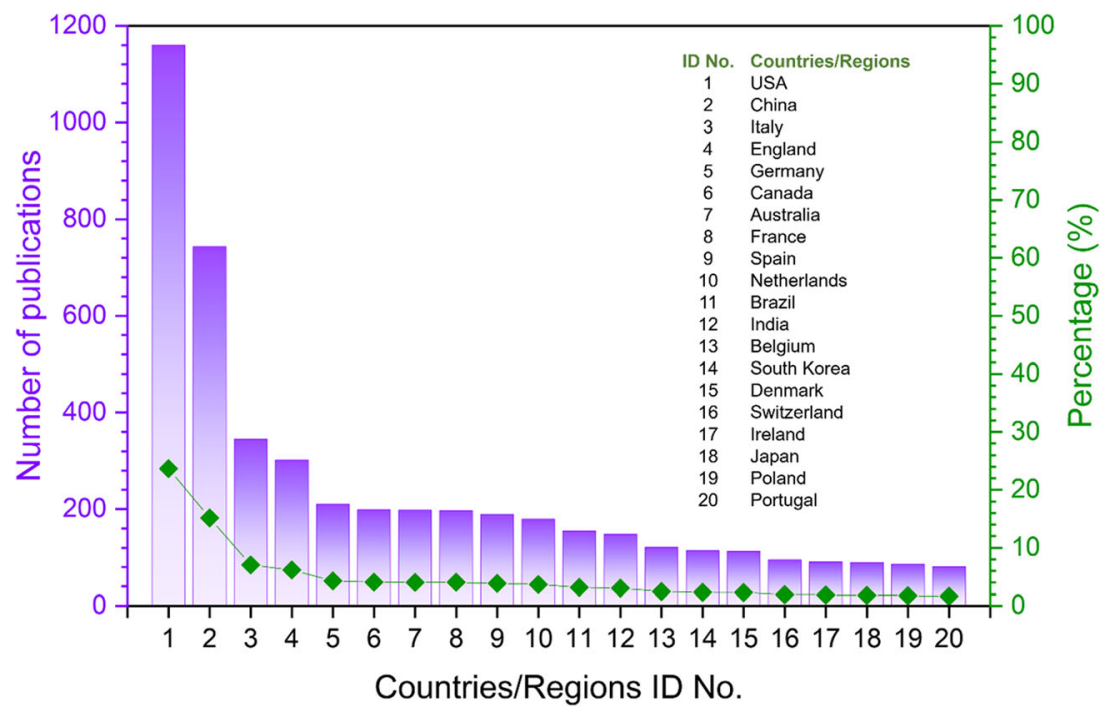


Table 1 The top 20 most publishing research institutes

\begin{tabular}{ll}
\hline ID no. & Research Institute \\
\hline 1 & Chinese Academy of Sciences \\
2 & USDA ARS \\
3 & Ghent University \\
4 & US FDA \\
5 & Wageningen University \\
6 & China Agricultural University \\
7 & Cornell University \\
8 & INRA \\
9 & University of California, Davis \\
10 & Zhejiang University \\
11 & Technical University of Denmark \\
12 & Iowa State University \\
13 & University of Copenhagen \\
14 & University of Florida \\
15 & University of Maryland \\
16 & University of Guelph \\
17 & University of Georgia \\
18 & Texas A\&M University \\
19 & Istituto Superiore di Sanità \\
20 & University of Minnesota \\
\hline &
\end{tabular}

Table 2 summarized the top 20 most-cited articles on environment and food safety. As revealed by Table 2, the research on environment and food safety is diverse, and there are quite a few research directions which received a lot of attention. Generally, the research topics disclosed by the most cited papers included food inspection/detection technique, heavy metal pollution, food additives, food packaging, food allergy, food pesticide, foodborne pathogen and diseases, microplastics, food processing, and production. Various food inspection/detection techniques have been reported, including electrochemical strategies to detect gallic acid in food (Badea et al. 2019), thermal imaging technique coupled with chemometrics (Mohd Ali et al. 2020), paper-based analysis device for rapid food safety detection (Qi et al. 2020), linescan spatially offset Raman spectroscopy technique for subsurface inspection of food (Qin et al. 2017), surface-enhanced Raman spectroscopy for detection of mycotoxins in food (Wu et al. 2021b), chromatography, and mass spectrometry (Pauk et al. 2021; Suman et al. 2021). In addition, heavy metal pollution has posed great threats on food safety, and a lot of studies are conducted, including the soil heavy metal pollution and food safety (Qin et al. 2021) and the impacts of various heavy metals (e.g., cadmium, lead, arsenic) on food safety and human health (Corguinha et al. 2015; Suhani et al. 2021). Furthermore, there are a variety of food additives used in different situations. For example, feed additives such as antibiotics have been used in animal nutrition; however, the use of antibiotics can cause antimicrobial resistance which can further increase the morbidity and mortality of diseases (Silveira et al. 2021). Therefore, as will be discussed below, laws and regulations are needed to strictly control the use of food additives. Furthermore, foodborne pathogen also has strong impacts on food safety. As an effective way to kill or inhibit foodborne pathogen, antimicrobial food packaging is gaining growing research interest in recent years (Woraprayote et al. 2018; Motelica et al. 2020; Alizadeh-Sani et al. 2021).

$T C$, total citations; the TC data was collected based on Web of Science core collection; $P Y$, publishing year

As shown in Supplementary Figure 1 and Supplementary Figure 2, food, safety, and environment were the top three most common words in titles. The following ones were assessment, health, risk, and environmental. It is well known that environmental pollution can pose risks on food safety and finally threatens human health. A further analysis revealed that a lot of studies were related to risk assessment, such as risk assessment of antimicrobial resistance (Likotrafiti et al. 2018; Pires et al. 2018), risk assessment of heavy metals (Yasotha et al. 2020), risk assessment of pesticide (Frische et al. 2014), risk assessment of veterinary drugs (Tsai et al. 2019), environmental risk assessment (More et al. 2020), and health risk assessment (Akhbarizadeh et al. 2020). The next one was efficacy, which was usually combined together with safety, such as safety and efficacy of feed additives (Bampidis et al. 2020). Besides, Listeria monocytogenes was intensively studied by researchers (Anast et al. 2020; Kawacka et al. 2020; Wu et al. 2020b). Another common word was analysis, such as analysis of herbicide (Pan et al. 2020), analysis of bacteria (Kang et al. 2020), and analysis of microplastics (Primpke et al. 2020). Other common research topics revealed by title analysis included but are not limited to food quality, food production, food processing, food additive, food contamination, detection of food contaminants, food microbiology, environmental impact, as well as water, soil, animal, fish, meat, and dairy.

The top 20 most used keywords were listed in Table 3 (more details are provided in supplementary data). It could be seen that microbiology was closely related to food safety, and a lot of studies were conducted on Listeria monocytogenes, biofilm, salmonella, and antibiotic resistance. In addition, additives, such as zootechnical additives and nutritional additives, were also intensively investigated by researchers. Other topics included aquaculture, poultry, and agriculture. Another keyword worth mentioning was food security. Food security is different with food safety. Briefly, food security is a more inclusive term and focuses more on the availability of food while food safety is about the quality of food. On the other hand, food security and food safety are closely related to each other (Vipham et al. 2020). For instance, if food security becomes a big issue, then usually food safety is not guaranteed, and vice versa. 
Table 2 Summary of the top 20 most-cited papers

\begin{tabular}{|c|c|c|c|c|}
\hline No. & Reference & $\mathrm{TC}$ & PY & Brief summary \\
\hline 1 & (Li et al. 2010) & 2236 & 2010 & $\begin{array}{l}\text { This paper reported an improved spectroscopy technique } \\
\text { which could be used for food safety inspection. }\end{array}$ \\
\hline 2 & $\begin{array}{l}\text { (Nagajyoti et al. } \\
\text { 2010) }\end{array}$ & 1452 & 2010 & $\begin{array}{l}\text { This paper reviewed the occurrence of common heavy metals } \\
\text { and their toxicity on plants. }\end{array}$ \\
\hline 3 & $\begin{array}{l}\text { (Järup and Åkesson } \\
\text { 2009) }\end{array}$ & 1250 & 2009 & This paper reviewed the effects of cadmium on human health. \\
\hline 4 & (Weir et al. 2012) & 1102 & 2012 & $\begin{array}{l}\text { This paper studied the amount of titanium dioxide additive in } \\
\text { common food and personal care products and discussed its } \\
\text { effects. }\end{array}$ \\
\hline 5 & (Kenawy et al. 2007) & 1016 & 2007 & $\begin{array}{l}\text { This paper did a review on antimicrobial polymers which } \\
\text { might be useful in food packaging and storage. }\end{array}$ \\
\hline 6 & (Friedman 2003) & 759 & 2003 & $\begin{array}{l}\text { This paper reviewed acrylamide which could be present in } \\
\text { food products and could have negative effects on human } \\
\text { health. }\end{array}$ \\
\hline 7 & $\begin{array}{l}\text { (Sicherer and } \\
\quad \text { Sampson 2014) }\end{array}$ & 699 & 2014 & This paper reviewed food allergy. \\
\hline 8 & $\begin{array}{l}\text { (Damalas and } \\
\text { Eleftherohorinos } \\
\text { 2011) }\end{array}$ & 651 & 2011 & This paper reviewed food pesticide. \\
\hline 9 & $\begin{array}{l}\text { (Gandhi and } \\
\text { Chikindas 2007) }\end{array}$ & 582 & 2007 & This paper reviewed foodborne pathogen: Listeria. \\
\hline 10 & $\begin{array}{l}\text { (Van Cauwenberghe } \\
\text { and Janssen 2014) }\end{array}$ & 574 & 2014 & This paper revealed the existence of microplastics in bivalves. \\
\hline 11 & (Newell et al. 2010) & 548 & 2010 & This paper reviewed foodborne diseases. \\
\hline 12 & (Hong et al. 2005) & 513 & 2005 & This paper reviewed bacillus probiotics. \\
\hline 13 & $\begin{array}{l}\text { (Humphrey et al. } \\
\text { 2007) }\end{array}$ & 479 & 2007 & $\begin{array}{l}\text { This paper reviewed campylobacters from the perspective of } \\
\text { food production. }\end{array}$ \\
\hline 14 & $\begin{array}{r}\text { (Koopmans and } \\
\text { Duizer 2004) }\end{array}$ & 479 & 2004 & This paper studied foodborne viruses. \\
\hline 15 & (Kathariou 2002) & 476 & 2002 & $\begin{array}{l}\text { This paper reviewed Listeria monocytogenes from the } \\
\text { perspective of food safety. }\end{array}$ \\
\hline 16 & (Su and Liu 2007) & 445 & 2007 & $\begin{array}{l}\text { This paper reviewed vibrio parahaemolyticus from the } \\
\text { perspective of seafood safety. }\end{array}$ \\
\hline 17 & (Lacey et al. 2001) & 432 & 2001 & $\begin{array}{l}\text { This paper reviewed insect pathogens as biological control } \\
\text { agents. }\end{array}$ \\
\hline 18 & (Tompkin 2002) & 423 & 2002 & $\begin{array}{l}\text { This paper was about Listeria monocytogenes control during } \\
\text { food processing. }\end{array}$ \\
\hline 19 & (Silvestre et al. 2011) & 414 & 2011 & $\begin{array}{l}\text { This paper reviewed food packaging using polymer } \\
\text { nanotechnology. }\end{array}$ \\
\hline 20 & $\begin{array}{l}\text { (Frederiksen et al. } \\
\text { 2009) }\end{array}$ & 414 & 2009 & This paper reviewed human exposure to PBDEs. \\
\hline
\end{tabular}

Generally, the results revealed by keywords analysis were in consistent with the above title and keywords analysis.

The keywords network graph revealed some interesting results. As shown in Figure 5, the network had three centers, namely the "food safety"-centered network, the "safety"-centered network and the "efficacy"centered network. Interestingly, the "safety"-centered network and the "efficacy"-centered network were closely related, while they were relatively unrelated with the "food safety"-centered network. Furthermore, the results again uncovered that food safety involved many aspects, many of which were already discussed above.
The publications in this study were divided into over 200 Web of Science categories (more details are provided in supplementary data). The top $20 \mathrm{Web}$ of Science categories were shown in Figure 6. Undoubtedly, the Food Science \& Technology category ranked the first place, followed by the Environment Sciences category. As revealed by Figure 6, food safety was closely related to microbiology, chemistry, and agriculture. Microorganisms such as foodborne pathogens pose great threats on food safety and a lot of studies are focusing on it. For instance, Lin et al (Lin et al. 2021) studied the role of Salmonella Hessarek, an emerging foodborne pathogen, in egg safety. Anyogu et al. (Anyogu et al. 2021) reviewed the microorganisms and indigenous fermented 
Table 3 The top 20 most used keywords

\begin{tabular}{lll}
\hline Keyword & Number of publications & Rank \\
\hline Food safety & 710 & 1 \\
Safety & 262 & 2 \\
Efficacy & 170 & 3 \\
Environment & 157 & 4 \\
Listeria monocytogenes & 129 & 5 \\
Risk assessment & 108 & 6 \\
Salmonella & 92 & 7 \\
Food & 91 & 8 \\
Food security & 57 & 9 \\
Zootechnical additive & 57 & 9 \\
Sustainability & 52 & 11 \\
Heavy metals & 49 & 12 \\
Agriculture & 46 & 13 \\
Biofilm & 45 & 14 \\
Antibiotic resistance & 43 & 15 \\
Aquaculture & 43 & 15 \\
Poultry & 42 & 17 \\
Nutrition & 41 & 18 \\
Zootechnical additives & 41 & 18 \\
Nutritional additive & 40 & 20 \\
\hline
\end{tabular}

foods with a focus on microbial food safety hazards. Van Boxstael et al. (2013) studied the impacts of bacterial pathogens and viruses on food safety in the fresh produce chain. Also, a lot of studies are focusing on food safety and chemistry, such as untargeted food chemical safety assessment (Delaporte et al. 2019), chemical safety of recycled food packaging (Geueke et al. 2018), and chemical food safety hazards of sausages (Halagarda et al. 2018). Furthermore, studies on food safety and agriculture include but are not limited to chemical and biological risks in urban agriculture (Buscaroli et al. 2021), biosensors for sustainable agriculture and food safety (Griesche and Baeumner 2020), agricultural soil contamination, and the impact on food safety (Wang et al. 2019b). In addition, the Materials Science category was also on the top list, which indicated that materials are also important research directions in environment and food safety. A further analysis revealed the common materials studied by researchers, including biomaterials, food packaging materials, biodegradable materials, coating materials, sensors and biosensors for food detection, and nanoparticles. The research area analysis showed similar results with Web of Science categories (Supplementary Table 3).

\section{Strategies to protect environment and ensure food safety}

The above scientometric analysis revealed that the studies on environment and food safety were diversified and multidisciplinary. Further analysis of the above results disclosed the challenges and strategies to protect environment and ensure food safety. As discussed earlier, environment and food safety are closely related to each other. It should be noted that the environment here is not limited to the broad environment (e.g., air, water, soil) which the public are familiar with. In other words, in addition to the broad environment, there are also food-related environments which exist in various processes, including but are not limited to food processing, food packaging, food transportation, food storage, and food consumption. In order to ensure food safety, contaminants/ pollutants from the environmental side should be prevented from reaching the food side. An example of food chain pollution control is presented in Figure 7. It can be seen that from growing wheat to making bread, there are a variety of processes which could cause pollution and control strategies are needed, which are summarized as follows. Firstly, from wheat growing to wheat harvesting: the pollutants/contaminants could be taken in or migrate into the wheat via contaminated soil, water, and air, and therefore strategies are needed to prevent soil, water, and air from being contaminated, such as reducing the use of pesticides and fertilizers. Secondly, initial processing of wheat: after the wheat is harvested, traditionally
Fig. 5 Keywords network graph. Keywords whose cooccurrence exceeded 10 times were connected with lines

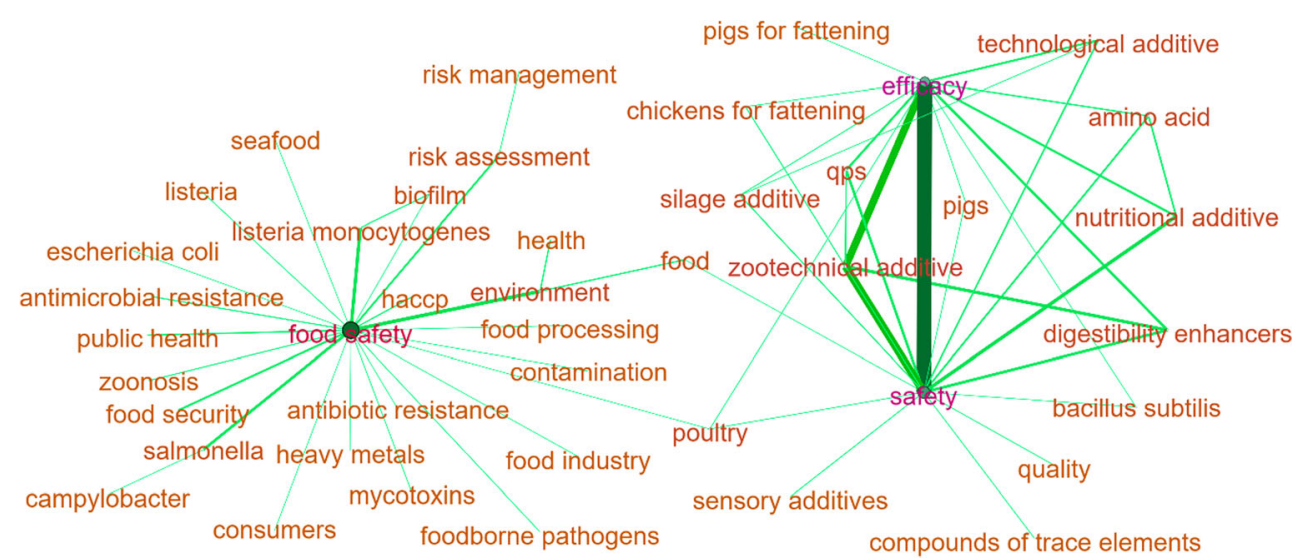


Fig. 6 Number of publications and corresponding percentage of the top $20 \mathrm{Web}$ of Science categories

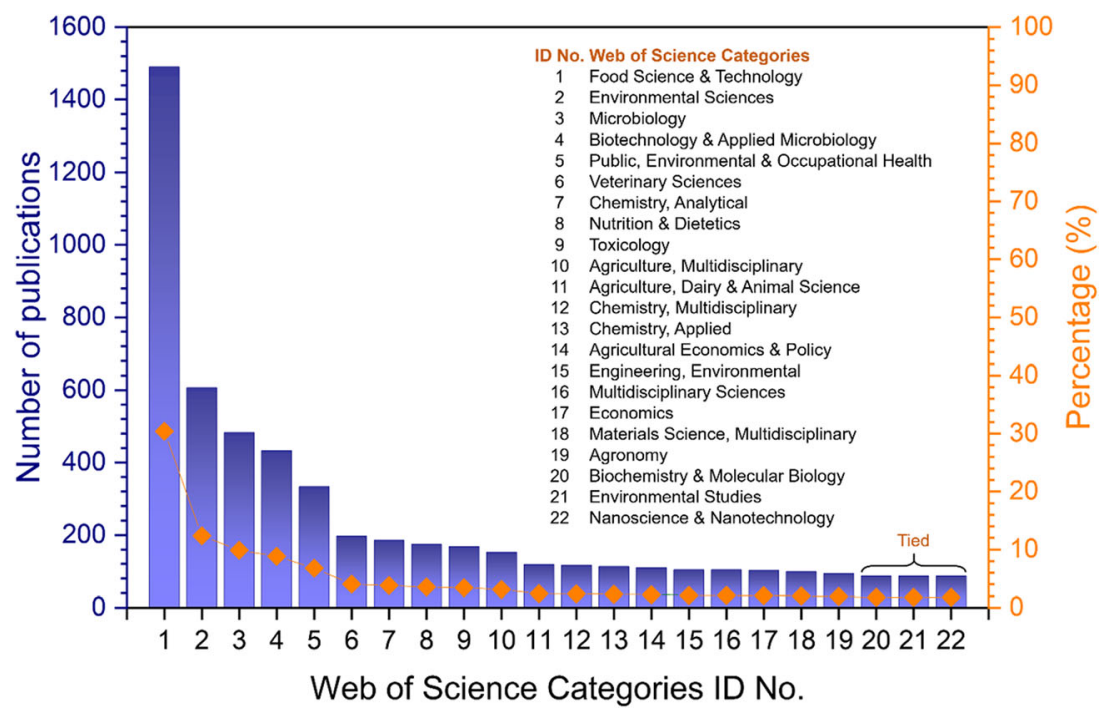

it needs to be dried by the farmers before it is sold. During this process, contamination can easily occur if the wheat is dried directly on the road which is common in rural China. In addition, the containers of the harvested wheat are also sources of pollution which should be carefully controlled. Alternatively, the pollution can be avoided if the wheat is directly sold and transported to the flour mill from the farm without being dried by the farmers. Thirdly, during the transportation processes (e.g., from farm to flour mill, from flour mill to bread bakery, from bread bakery to supermarkets), contamination can also take place and control strategies are needed. Fourthly, during the wheat processing at the mill and bread baking at the bakery, contamination can take place due to environment exposure, insufficient frequency and quality of facility washing and cleaning, use of additives, etc. Fifthly, during the bread packaging process, the workers can be an important source of bread contamination if the bread is packed manually. Finally, when the consumers buy the bread and do not consume the bread timely, the bread can decay. Based on the above discussion, the food chain pollution control can be generally categorized into the following sections: source pollution (i.e., soil, water, air) control, pollution control during food processing, pollution control during food packaging, pollution control during transportation, pollution control during storage, and pollution control during consumption.

Especially, based on the type of chemicals, the contaminants/pollutants can be categorized into pesticides and herbicides, heavy metals, food additives, pathogens, microplastics, antibiotics, and so on (Van Boxstael et al. 2013; Tóth et al. 2016; He et al. 2019b; Rajmohan et al. 2019; Bonerba et al. 2021). Therefore, the corresponding strategies are to control the use of chemicals and materials which can produce these contaminates. For example, as will be discussed in the following section, microplastics come from the wide use of plastics and are receiving growing concern. In order to reduce the amount of microplastics, the use of plastics should be controlled or restricted. Based on the media of migration, these contaminants can reach at the food side via air, water, and soil. Therefore, the corresponding strategies are to remove contaminants from air, water and soil. Alternatively, strategies can be deployed to prevent these contaminants from contacting the food. For example, as will be discussed later, food packaging is a common strategy to protect food from being contaminated by the environment (Risyon et al. 2020). To sum up, by controlling the sources and migration routes of food contaminants, food safety can be improved. Furthermore, in order to ensure food safety, whole process monitoring techniques and platforms are necessary. A lot of studied have been conducted on food safety monitoring. For example, De Oliveira et al. (2021) proposed that environmental monitoring programs (EMPs) are necessary to ensure food safety and quality. The EMPs are used to prevent environmental contamination of the finished product, via checking the cleaning-sanitation procedures, and other environmental pathogen control programs with a range of sampling analysis. Medina et al. (Medina et al. 2019) proposed food fingerprints as an effective tool to monitor food safety. Weng et al. (Weng and Neethirajan 2017) reviewed microfluidics as an effective method to realize rapid, cost-effective, and sensitive detection of food contaminants such as foodborne pathogens, heavy metals, additives, and pesticide residues. Other monitoring methods/techniques/devices include but are not limited to $\mathrm{pH}$-sensitive smart packaging films (Alizadeh-Sani et al. 2020), point-of-care detection devices (Wu et al. 2017), and real-time pathogen monitoring via a nanotechnology-based method (Weidemaier et al. 2015). Food safety monitoring can be done by either government officials or the relative bodies (e.g., self-monitoring), or both. Furthermore, from the time the food raw materials are being cultivated in the farmland, pasture, fishing ground or other places, to the time the 


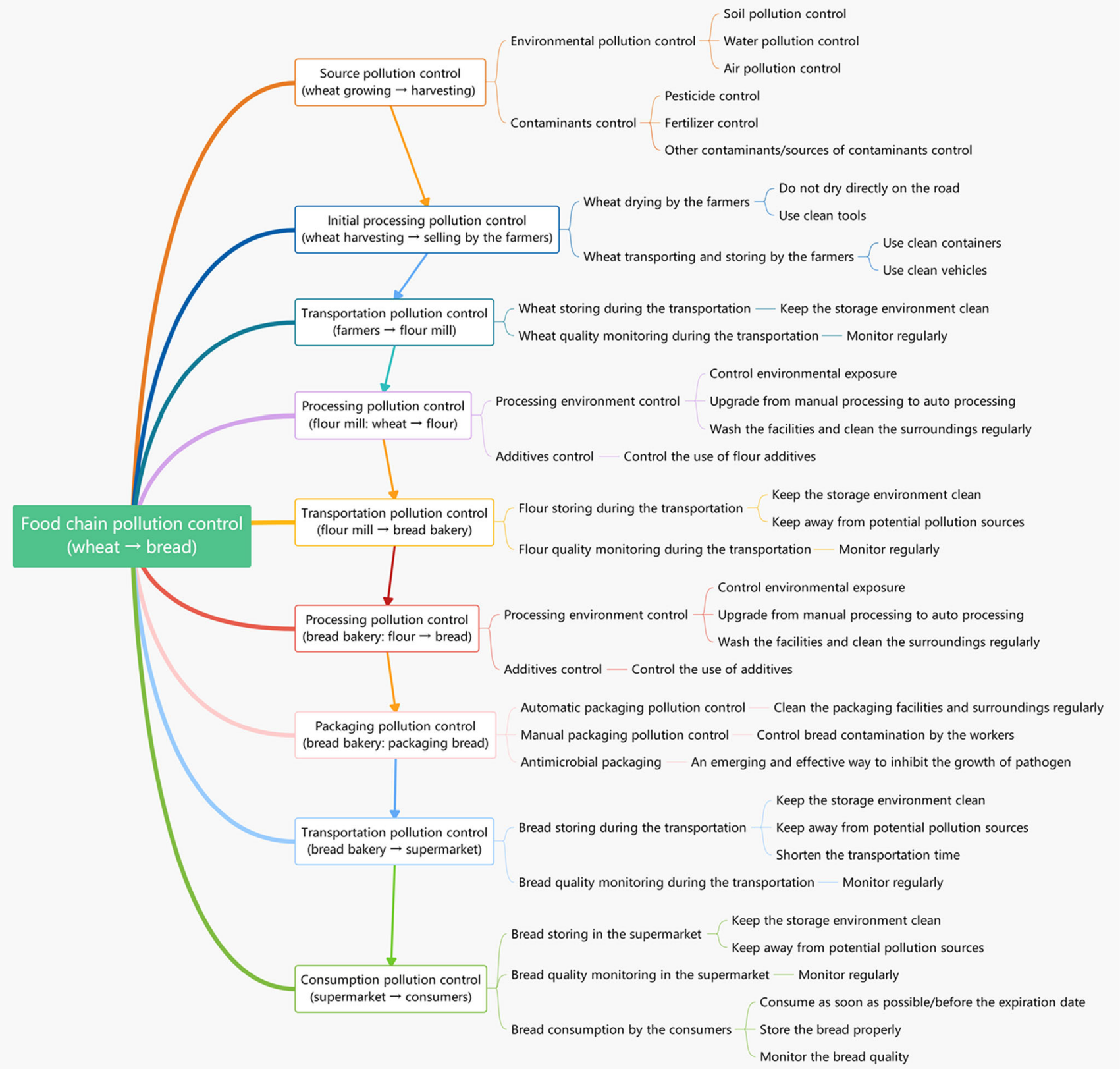

Fig. 7 Demonstration of the whole food chain pollution control from wheat growing to bread consuming

food is being consumed by customers, inspecting and detecting should be deployed. This can be done by the government officials and/or the stakeholders. Although the term "inspection" and "detection" are often used as the same, here, food safety inspection is regarded as an administrative strategy, which is carried out by governmental officials to check whether the relative workers/factories/bodies have followed the food safety requirements/regulations, while food safety detection is regarded as a technique-based strategy, which is used to detect food contaminants and check whether the quality of the food meets the relative standards. Meanwhile, food safety laws need to be enacted to discourage or prevent the relative workers/factories/bodies from affecting the food safety, whether purposely or not.

On the other hand, during the process of food production, the environment can be polluted as well. For example, in order to increase crop yield, a lot of fertilizers are used, which will migrate into the soil and water bodies, and cause soil and water pollution. Therefore, the use of fertilizers should be restricted, which can be realized through agricultural innovations (Liu et al. 2021), government policies (van Wesenbeeck et al. 2021), etc. Furthermore, during food processing, a large amount of solid waste or/and wastewater are produced which can cause environmental pollution. Therefore, techniques are 
needed to dispose the food waste properly. Especially, food waste usually contains high amount of organic compounds and therefore falls into the category of biomass, which can be used to produce useful biochemicals like biofuels (Wainaina et al. 2018; Chun et al. 2019). For example, agrofood waste is an important source of lignocellulosic biomass; the valorization of lignocellulosic biomass is regarded as a sustainable source of energy and has the potential to replace conventional fossil fuels (Ong and $\mathrm{Wu} 2020$; Lee and $\mathrm{Wu}$ 2021; Lee et al. 2021; Mankar et al. 2021; Zhenquan et al. 2021). Furthermore, the concepts of recycling and sustainable development can be deployed. For example, food packaging materials can be recycled and used again. Another example is to use cloth bags to replace plastic bags when shopping. These strategies can reduce the burden on the environment as the amount of food-related waste can be reduced. In addition, novel environment-friendly materials (e.g., biodegradable polymers) can be developed and used in food industries (Stoica et al. 2020; Cheng et al. 2021). To summarize, the above strategies to protect environment and ensure food safety are presented in Figure 8.

\section{Emerging studies on environment and food safety}

Scientometric analysis is powerful in disclosing the research trend and is relatively subjective compared to conventional type of review. However, as it is essentially a statistical study which relies on a huge amount of data, it is less effective to reveal the emerging research directions which could be ignored in the scientometric study. Therefore, it is necessary and important to carry out a subjective discussion on emerging studies on environment and food safety as an indispensable supplement (Figure 9).

\section{Emerging contaminants}

There are various contaminants affecting environment and food safety. Among the various types of contaminants, emerging contaminants, such as microplastics, are receiving growing concern due to their potential effects on human health (Sarker et al. 2020). Because of the wide application of plastics, microplastics are found almost everywhere in the environment, including soil, water, and air (Álvarez-Lopeztello et al. 2020; Chen et al. 2020; Wang et al. 2021c). For example, microplastics are reported to exist in bottled water (Zhou et al. 2021) and take-out food plastic containers (Du et al. 2020). Furthermore, researchers have found that microplastics could serve as the carrier for many other contaminants such as heavy metals and antibiotics (Zhou et al. 2019; Purwiyanto et al. 2020; Yu et al. 2020b). Studies reveal that the ability to absorb heavy metals increase as the microplastics age (Lang et al. 2020). As a result, the risks of microplastics on environment, food safety, and human health could be significantly increased. However, the research on microplastics is still at an early stage, and more efforts are needed to uncover the world of microplastics. For example, there is no standard procedures to extract, identify, and quantify microplastics so results by different methods could be different and uncomparable (Kumar et al. 2020; Zhou et al. 2020). Meanwhile, due to the various sizes, shapes, forms, sources, and types of microplastics, it is difficult and time-consuming to characterize microplastics (Wu et al. 2020a). Therefore, it is important to develop new methods for rapid and effective detection of microplastics (Li et al. 2020c).

In addition to microplastics, there are other emerging contaminants which can have negative effects on the environment, food safety, and human health. These emerging contaminants include but are not limited to persistent organic pollutants (Titchou et al. 2021), antibiotics (Koch et al. 2021), personal care products (Scaria et al. 2021), pharmaceuticals (Chaturvedi et al. 2021), endocrine-disrupting compounds

Fig. 8 Strategies to protect environment and ensure food safety

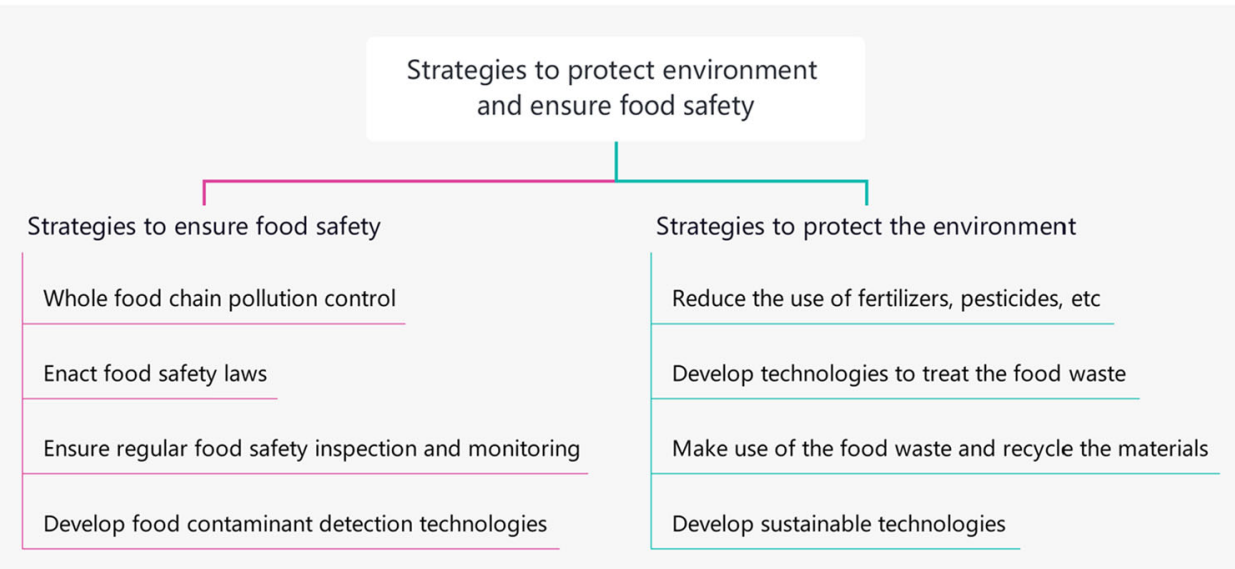




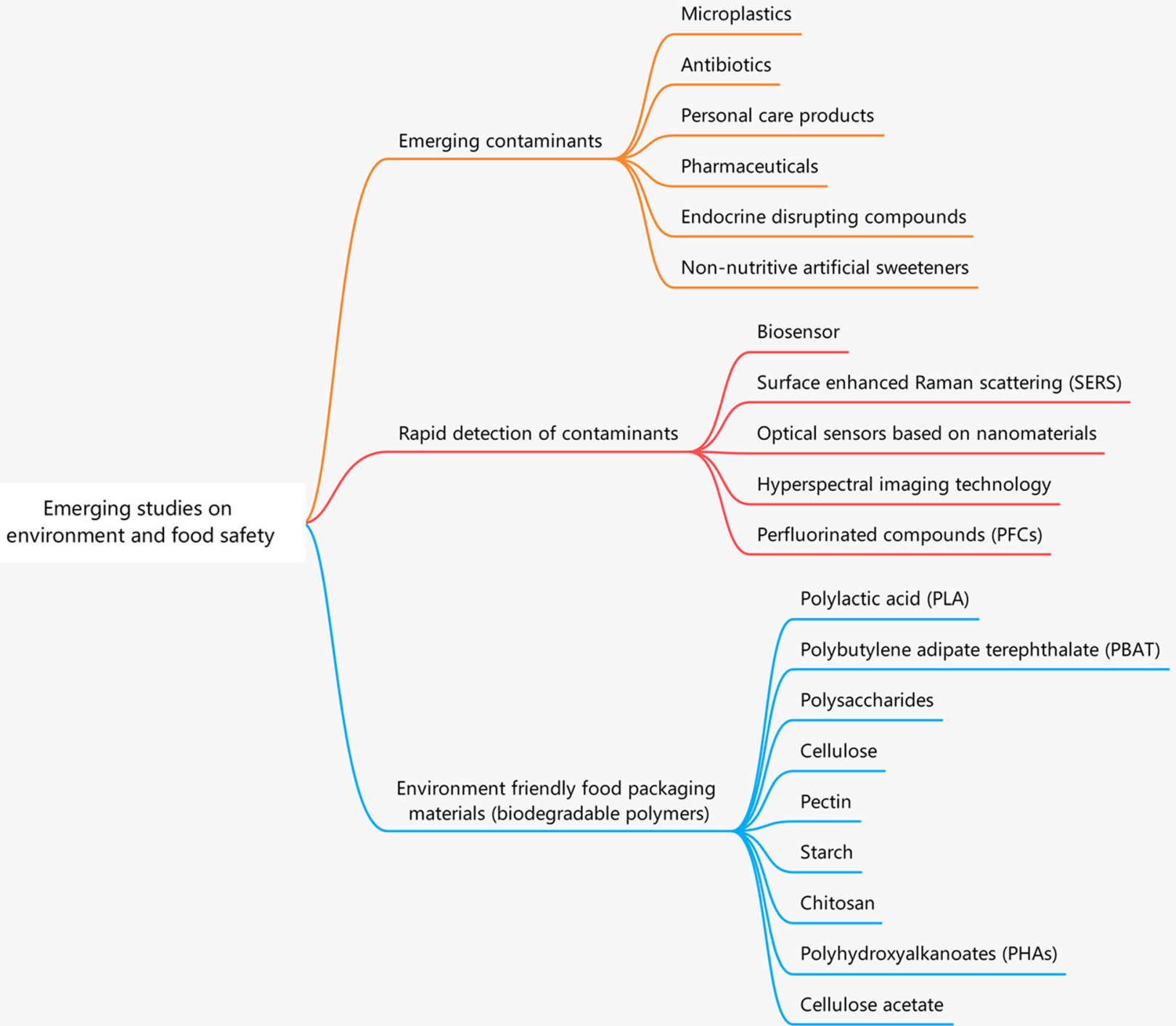

Fig. 9 Emerging studies on environment and food safety

(Kasonga et al. 2021), and non-nutritive artificial sweeteners (Praveena et al. 2019). More research efforts are needed to gain a better understanding of the migration, degradation, accumulation characteristics, as well as the potential risks of these contaminants.

\section{Rapid detection of contaminants}

Not limited to the detection of microplastics, it is also necessary to develop rapid detection methods for common contaminants. For example, due to the widespread application of pesticides in agriculture, pesticide residue is becoming a serious environment and food safety issue (Farahy et al. 2021). Traditionally, food contaminants are detected by instrumental analysis, such as chromatography and mass spectrometry (Ye et al. 2019). However, the instrumental analysis process is expensive, complicated, and time-consuming (Zhang et al. 2019). Furthermore, the contaminants are usually in low concentration, but can accumulate gradually in human bodies via bioconcentration. Therefore, it is important to develop rapid method to detect trace-level concentration of food contaminants. Biosensor is an emerging and promising technology in detecting food contaminants such as pesticides, and a variety of biosensors have been developed in recent years (Majdinasab et al. 2018, 2019). For example, Ouyang et al. (Ouyang et al. 2021) developed a sensitive biosensor to detect carbendazim pesticide residues based on luminescent resonance energy transfer from aptamer-labelled upconversion nanoparticles to manganese dioxide nanosheets. Capobianco et al. (Capobianco et al. 2021) developed an enzyme-linked immunoelectrochemical biosensor to detect pathogenic bacteria in large volume food samples without subsampling. Wang 
et al. (Wang et al. 2019a) developed a magnetic quantum dotbased lateral flow biosensor to detect protein toxins in food samples. Kaushal et al. (Kaushal et al. 2019) developed a novel biosensor using gold nanorods capped by glycoconjugates which demonstrated potential in optical detection and ablation of foodborne bacteria. Generally, a biosensor is mainly composed of a biological sensing element (also known as bioreceptor), a transducer, and an electrical output system (Santana Oliveira et al. 2019; Majdinasab et al. 2021). The bioreceptor will interact with the analyte, and the transducer will convert the interaction into a detectable signal, which is then processed and displayed on the output system. Common materials used in the biological element include antibodies, enzymes, nucleic acids, antigens, aptamers, whole cells, and bacteriophage (Arora et al. 2011; Rotariu et al. 2016; Griesche and Baeumner 2020; Singh et al. 2020b. Biosensor technology has obvious advantages compared to traditional detection technologies. It is rapid, highly sensitive and selective, accurate, relatively compact, and easy to operate (Dominguez et al. 2017). However, there are still some challenges to widely commercialize biosensors, such as limited lifetime of the biological sensing elements and limited range of analytes that can be detected (Di Nardo and Anfossi 2020). Furthermore, as a specific type of biosensor is only effective in detecting a specific type of contaminant, more efforts are needed to develop integrated biosensors which can detect different types of containments simultaneously (Majdinasab et al. 2020). In addition to biosensors, there are also a variety of other reported methods for rapid detection of food contaminants, such as surface-enhanced Raman scattering (SERS) (Yao et al. 2021), optical sensors based on nanomaterials (Chen et al. 2021a), hyperspectral imaging technology (He and Sun 2015), and perfluorinated compounds (PFCs) (Cai et al. 2021).

\section{Environment friendly food packaging materials}

As revealed above, food packaging is closely related to food safety. Although there are different kinds of food packaging materials, the non-biodegradable plastic materials (e.g., polyethylene, polypropylene, polyvinyl chloride, polystyrene, polyethylene terephthalate) are the most common ones and are widely used in our daily life (Cazón and Vázquez 2021). However, the non-biodegradable plastic materials have caused serious environmental problems, commonly known as white pollution. Especially, because of the coronavirus pandemic, take-out food becomes more popular. As plastic materials are the most common packaging materials for take-out food, the demand for plastic materials increases dramatically. Meanwhile, plastic materials also have food safety issues. It is found that the monomer residues used to make plastic polymers could migrate into food, which could cause health problems (Pilevar et al. 2019). Especially, the migration rate is not only affected by the quality of these materials, but also affected by the food properties. In addition to monomer residues, additives in these plastic materials could also migrate into food, causing health risks (Hahladakis et al. 2018). For example, bisphenol A, a common additive used in plastics, can adversely affect human endocrine system, block normal cell function, affect thyroid hormone, affect testosterone levels, and could also possibly induce cancer (Huang et al. 2019; Vilarinho et al. 2019). Another very common additive in plastics is phthalates, which is used as plasticizer to soften the plastics. It is reported that phthalates in plastic bottles could migrate into water, and the amount of migration increases as the storage time increases (Luo et al. 2018). Similar to bisphenol A, phthalates can also disrupt human endocrine system and cause bad effects on human health (Wang et al. 2018). Not limited to bisphenol A and phthalates, there are many types of plastic additives which could migrate into food and cause food safety issues.

As the conventional non-biodegradable plastics can cause both environmental problems and food safety issues, a lot of studies are carried out to find alternatives to nonbiodegradable plastics for food packaging. Biodegradable polymers are regarded as the one of the most promising alternatives for food packaging (Othman 2014). As its name indicates, biodegradable polymers can be decomposed by microorganisms. Common biodegradable polymers studied as food packaging materials include but are not limited to polylactic acid (PLA) (Swaroop and Shukla 2018, 2019; Mohamad et al. 2020), polybutylene adipate terephthalate (PBAT) (Pattanayaiying et al. 2019), polysaccharides (such as starch (Osorio et al. 2019; Menzel 2020; Saraiva Rodrigues et al. 2020), cellulose (Balasubramaniam et al. 2020; Riaz et al. 2020), pectin (Nešić et al. 2018), chitosan (Haghighi et al. 2020; Priyadarshi and Rhim 2020)), polyhydroxyalkanoates (PHAs) such as polyhydroxybutyrate (PHB) (Adeleye et al. 2020; Fernandes et al. 2020; Shahid et al. 2020), polycaprolactone (PCL) (Khalid et al. 2018; Mugwagwa and Chimphango 2020), and cellulose acetate (Xie and Hung 2018; Rajeswari et al. 2020).

However, in addition to high production cost, there are some critical technical challenges which must be solved so as to widely commercialize biodegradable polymers and replace conventional plastics (Pérez-Arauz et al. 2019). Generally, biodegradable polymers have low thermal stability, low mechanical stability, and poor barrier properties (Risyon et al. 2020). One way to improve its performance is to add additives during production. For example, Risyona et al. (Risyon et al. 2020) prepared PLA-based film using different concentrations of halloysite nanotubes as additives. They found that the PLA film with $3.0 \mathrm{wt}$.\% of halloysite nanotubes demonstrated optimal properties. Dash et al. (Dash et al. 2019) prepared starch and pectin-based film using different concentrations of titanium dioxide nanoparticles. They found that 
addition of the nanoparticles could effectively improve the mechanical properties and moisture barrier properties of the films. However, similarly to conventional plastics, these additives might also migrate into food (He et al. 2019a). Another strategy being intensively studied is polymer blending, which integrates the merits of different polymers (de Oliveira et al. 2020). For example, Rajeswari et al. (Rajeswari et al. 2020) blended polysaccharides and cellulose acetate together, and the resulting film showed improved thermal stability and tensile strength. The prepared films also demonstrated antimicrobial properties towards certain types of microorganisms. Sangroniz et al. (Sangroniz et al. 2018) blended poly(butylene adipate-co-terephthalate) with poly(hydroxi amino ether), and the resulting film showed great improvement of barrier properties. However, polymer blending could also have its drawback. For example, if the blending polymers are immiscible with each other, the mechanical strength and barrier properties of the resulting materials will be affected (Corres et al. 2020).

\section{Conclusions, challenges, and future research directions}

In this review, a scientometric-based statistical study was firstly conducted on the research of environment and food safety, which revealed that the research on environment and food safety was growing steadily from 2001 to 2020. Interestingly, statistical analysis of the most-cited papers, titles, abstracts, keywords, and research areas revealed that the research on environment and food safety is diverse and multidisciplinary. Furthermore, strategies to protect the environment and ensure food safety are discussed, such as controlling the use of chemicals and materials which can produce environment and food contaminates, preventing these contaminants from contacting the food, developing whole process monitoring techniques and platforms, and utilizing the food waste properly. In addition, emerging research topics are discussed, such as emerging contaminants, rapid detection of contaminants, and environment friendly food packaging materials.

Although environment and food safety are receiving growing concern, there are still some very challenging issues. These challenges can be categorized into four parts. Firstly, it is challenging to eliminate environmental pollutions (Hao et al. 2018; Christy et al. 2021). Air pollution, water pollution, and soil pollution are still serious environmental problems in many parts of the world (Wu et al. 2016, 2021a; Rajeswari et al. 2019; Shen et al. 2021b). Although a lot of studies have been carried out, the mechanisms of some pollutions (e.g., haze weather) are still unclear (Shen et al. 2020; Wang et al. 2021a). Secondly, it is challenging to dispose food waste effectively and efficiently. It is reported that a substantial amount of food waste is produced along the food supply chain (Aschemann-Witzel 2016; Li et al. 2019). Especially, food wastewater typically contains very complex components, and the treatment process is very energy intensive and costly. Thirdly, it is challenging to realize whole-process monitoring of contaminants, due to the diverse contaminants during food cultivation, processing, packaging, transportation, and retailing. Fourthly, the accurate effects of environmental pollution on human health are still unclear, and it is challenging to establish procedures to accurately assess the risks of environmental pollution on human health. For example, it is well reported that ozone pollution and PM2.5 pollution can cause negative effects on human health (Guan et al. 2021; Shen et al. 2021a; Wang et al. 2021b). However, the underlying mechanisms, accurate assessment procedures, and quantitative studies are still lacking. In order to address these challenges, more research efforts are needed to (1) uncover the underlying mechanisms of contaminant formation, migration and fate; (2) develop more cost-effective and sustainable food waste treatment and utilization technologies, targeting net zero emissions; (3) develop rapid detection methods and in situ monitoring technologies for environment and food safety; and (4) establish health risk assessment models and procedures.

Author contribution Conceptualisation: SJ and ZY; methodology: SJ; writing - original draft preparation: $S J$; writing - review and editing: FW, QL, HS, HW, and ZY; supervision: ZY; funding acquisition: ZY. All authors read and approved the final manuscript.

Funding This work was supported by the Beijing Municipal Commission of Education (grant no. PXM2019_014213_000007) and School Level Cultivation Fund of Beijing Technology and Business University for Distinguished and Excellent Young Scholars (grant no. BTBUYP2020).

Data availability All data generated or analyzed during this study are included in this published article.

\section{Declarations}

Ethics approval and consent to participate Not applicable

Consent for publication Not applicable

Competing interests The authors declare no competing interests.

\section{References}

Adeleye AT, Odoh CK, Enudi OC et al (2020) Sustainable synthesis and applications of polyhydroxyalkanoates (PHAs) from biomass. Process Biochem 96:174-193

Aghilinasrollahabadi K, Salehi M, Fujiwara T (2020) Investigate the influence of microplastics weathering on their heavy metals uptake in stormwater. J Hazard Mater 408:124439. https://doi.org/10.1016/j. jhazmat.2020.124439 
Ahmad T, Belwal T, Li L et al (2020) Utilization of wastewater from edible oil industry, turning waste into valuable products: a review. Trends Food Sci Technol 99:21-33. https://doi.org/10.1016/j.tifs. 2020.02.017

Akansha J, Nidheesh PV, Gopinath A et al (2020) Treatment of dairy industry wastewater by combined aerated electrocoagulation and phytoremediation process. Chemosphere 253:126652. https://doi. org/10.1016/j.chemosphere.2020.126652

Akhbarizadeh R, Moore F, Monteiro C et al (2020) Occurrence, trophic transfer, and health risk assessment of bisphenol analogues in seafood from the Persian Gulf. Mar Pollut Bull 154:111036. https://doi. org/10.1016/j.marpolbul.2020.111036

Alizadeh-Sani M, Moghaddas Kia E, Ghasempour Z, Ehsani A (2021) Preparation of active nanocomposite film consisting of sodium caseinate, $\mathrm{ZnO}$ nanoparticles and Rosemary essential oil for food packaging a0pplications. J Polym Environ 29:588-598. https://doi. org/10.1007/s10924-020-01906-5

Alizadeh-Sani M, Mohammadian E, Rhim J-W, Jafari SM (2020) pHsensitive (halochromic) smart packaging films based on natural food colorants for the monitoring of food quality and safety. Trends Food Sci Technol 105:93-144. https://doi.org/10.1016/j.tifs.2020.08.014

Álvarez-Lopeztello J, Robles C, del Castillo RF (2020) Microplastic pollution in neotropical rainforest, savanna, pine plantations, and pasture soils in lowland areas of Oaxaca, Mexico: Preliminary results. Ecol Indic 121:107084. https://doi.org/10.1016/j.ecolind.2020. 107084

Anast JM, Bobik TA, Schmitz-Esser S (2020) The cobalamin-sependent gene cluster of Listeria monocytogenes: implications for virulence, stress response, and food safety. Front Microbiol 11:60181

Anyogu A, Olukorede A, Anumudu C et al (2021) Microorganisms and food safety risks associated with indigenous fermented foods from Africa. Food Control 129:108227. https://doi.org/10.1016/j. foodcont.2021.108227

Arisekar U, Shakila RJ, Shalini R, Jeyasekaran G (2020) Human health risk assessment of heavy metals in aquatic sediments and freshwater fish caught from Thamirabarani River, the Western Ghats of South Tamil Nadu. Mar Pollut Bull 159:111496. https://doi.org/10.1016/j. marpolbul.2020.111496

Arora P, Sindhu A, Dilbaghi N, Chaudhury A (2011) Biosensors as innovative tools for the detection of food borne pathogens. Biosens Bioelectron 28:1-12. https://doi.org/10.1016/j.bios.2011. 06.002

Aschemann-Witzel J (2016) Waste not, want not, emit less: reducing food waste in the supply chain and at home can help to reduce carbon emissions. Science (80-) 352:408-409. https://doi.org/10.1126/ science.aaf 2978

Ayelign A, De Saeger S (2020) Mycotoxins in Ethiopia: current status, implications to food safety and mitigation strategies. Food Control 113:107163. https://doi.org/10.1016/j.foodcont.2020.107163

Badamasi I, Odong R, Masembe C (2019) Implications of increasing pollution levels on commercially important fishes in Lake Victoria. J Great Lakes Res 45:1274-1289. https://doi.org/10. 1016/j.jglr.2019.09.024

Badea M, di Modugno F, Floroian L et al (2019) Electrochemical strategies for gallic acid detection: potential for application in clinical, food or environmental analyses. Sci Total Environ 672:129-140. https://doi.org/10.1016/j.scitotenv.2019.03.404

Baki MA, Hossain MM, Akter J et al (2018) Concentration of heavy metals in seafood (fishes, shrimp, lobster and crabs) and human health assessment in Saint Martin Island, Bangladesh. Ecotoxicol Environ Saf 159:153-163. https://doi.org/10.1016/j.ecoenv.2018. 04.035

Bala A, Laso J, Abejón R et al (2020) Environmental assessment of the food packaging waste management system in Spain: understanding the present to improve the future. Sci Total Environ 702:134603. https://doi.org/10.1016/j.scitotenv.2019.134603
Balasubramaniam SPL, Patel AS, Nayak B (2020) Surface modification of cellulose nanofiber film with fatty acids for developing renewable hydrophobic food packaging. Food Packag Shelf Life 26:100587. https://doi.org/10.1016/j.fpsl.2020.100587

Bampidis V, Azimonti G, de Lourdes Bastos M et al (2020) Safety and efficacy of methyl cellulose for all animal species. EFSA J 18: e06212. https://doi.org/10.2903/j.efsa.2020.6212

Barnes SJ (2019) Understanding plastics pollution: the role of economic development and technological research. Environ Pollut 249:812821. https://doi.org/10.1016/j.envpol.2019.03.108

Bilal M, Iqbal HMN (2020) Transportation fate and removal of microplastic pollution - a perspective on environmental pollution. Case Stud Chem Environ Eng 2:100015. https://doi.org/10.1016/j. cscee. 2020.100015

Boguniewicz-Zablocka J, Klosok-Bazan I, Callegari A, Capodaglio AG (2020) Snack-food industry effluent pre-treatment for annatto dye and yeast removal: process improvement for effectiveness and sustainability. J Clean Prod 277:124117. https://doi.org/10.1016/j. jclepro.2020.124117

Bonerba E, Panseri S, Arioli F et al (2021) Determination of antibiotic residues in honey in relation to different potential sources and relevance for food inspection. Food Chem 334. https://doi.org/10.1016/ j.foodchem.2020.127575

Brennan L, Langley S, Verghese K et al (2020) The role of packaging in fighting food waste: a systematised review of consumer perceptions of packaging. J Clean Prod 281:125276. https://doi.org/10.1016/j. jclepro.2020.125276

Buscaroli E, Braschi I, Cirillo C et al (2021) Reviewing chemical and biological risks in urban agriculture: a comprehensive framework for a food safety assessment of city region food systems. Food Control 126:108085. https://doi.org/10.1016/j.foodcont.2021. 108085

Cai Y, Wang Q, Zhou B et al (2021) A review of responses of terrestrial organisms to perfluorinated compounds. Sci Total Environ 793: 148565. https://doi.org/10.1016/j.scitotenv.2021.148565

Capobianco JA, Armstrong CM, Lee J, Gehring AG (2021) Detection of pathogenic bacteria in large volume food samples using an enzymelinked immunoelectrochemical biosensor. Food Control 119: 107456. https://doi.org/10.1016/j.foodcont.2020.107456

Cazón P, Vázquez M (2021) Bacterial cellulose as a biodegradable food packaging material: a review. Food Hydrocoll 113:106530. https:// doi.org/10.1016/j.foodhyd.2020.106530

Chaturvedi P, Shukla P, Giri BS et al (2021) Prevalence and hazardous impact of pharmaceutical and personal care products and antibiotics in environment: a review on emerging contaminants. Environ Res 194:110664. https://doi.org/10.1016/j.envres.2020.110664

Chen D, Wang T, Ma Y et al (2020) Rapid characterization of heavy metals in single microplastics by laser induced breakdown spectroscopy. Sci Total Environ 743:140850. https://doi.org/10.1016/j. scitotenv.2020.140850

Chen H, Zhang L, Hu Y et al (2021a) Nanomaterials as optical sensors for application in rapid detection of food contaminants, quality and authenticity. Sensors Actuators B Chem 329:129135. https://doi. org/10.1016/j.snb.2020.129135

Chen Y, Awasthi AK, Wei F et al (2021b) Single-use plastics: production, usage, disposal, and adverse impacts. Sci Total Environ 752: 141772. https://doi.org/10.1016/j.scitotenv.2020.141772

Cheng H, Chen L, McClements DJ et al (2021) Starch-based biodegradable packaging materials: a review of their preparation, characterization and diverse applications in the food industry. Trends Food Sci Technol 114:70-82. https://doi.org/10.1016/j.tifs.2021.05.017

Christy EJS, Amalraj A, Rajeswari A, Pius A (2021) Enhanced photocatalytic performance of $\mathrm{Zr}(\mathrm{IV})$ doped $\mathrm{ZnO}$ nanocomposite for the degradation efficiency of different azo dyes. Environ Chem Ecotoxicol 3:31-41. https://doi.org/10.1016/j.enceco.2020.10.005 
Chun M, Zhenquan V, Yeong T (2019) Potential use of alkaline hydrogen peroxide in lignocellulosic biomass pretreatment and valorization a review. Renew Sust Energ Rev 112:75-86. https://doi.org/10. 1016/j.rser.2019.04.082

Corguinha APB, de Souza GA, Gonçalves VC et al (2015) Assessing arsenic, cadmium, and lead contents in major crops in Brazil for food safety purposes. J Food Compos Anal 37:143-150. https:// doi.org/10.1016/j.jfca.2014.08.004

Corres MÁ, Mayor Á, Sangroniz A et al (2020) Blends based on biodegradable poly(caprolactone) with outstanding barrier properties for packaging applications: the role of free volume and interactions. Eur Polym J 135:109869. https://doi.org/10.1016/j.eurpolymj.2020. 109869

Damalas CA, Eleftherohorinos IG (2011) Pesticide exposure, safety issues, and risk assessment indicators. Int. J. Environ. Res. Public Health 8:1402-1419

Dash KK, Ali NA, Das D, Mohanta D (2019) Thorough evaluation of sweet potato starch and lemon-waste pectin based-edible films with nano-titania inclusions for food packaging applications. Int J Biol Macromol 139:449-458. https://doi.org/10.1016/j.ijbiomac.2019. 07.193

De Oliveira MJ, Boué G, Prévost H et al (2021) Environmental monitoring program to support food microbiological safety and quality in food industries: a scoping review of the research and guidelines. Food Control 130:108283. https://doi.org/10.1016/j.foodcont. 2021.108283

de Oliveira TV, de Freitas PAV, Pola CC et al (2020) Development and optimization of antimicrobial active films produced with a reinforced and compatibilized biodegradable polymers. Food Packag Shelf Life 24:100459. https://doi.org/10.1016/j.fpsl.2019.100459

Delaporte G, Cladière M, Camel V (2019) Untargeted food chemical safety assessment: a proof-of-concept on two analytical platforms and contamination scenarios of tea. Food Control 98:510-519. https://doi.org/10.1016/j.foodcont.2018.12.004

Deshwal GK, Panjagari NR (2020) Review on metal packaging: materials, forms, food applications, safety and recyclability. J Food Sci Technol 57:2377-2392. https://doi.org/10.1007/s13197-01904172-Z

Di Nardo F, Anfossi L (2020) Commercial biosensors for detection of food additives, contaminants, and pathogens. Elsevier Inc.

Dominguez RB, Hayat A, Alonso GA, et al (2017) Nanomaterial-based biosensors for food contaminant assessment. Elsevier Inc.

Du F, Cai H, Zhang Q et al (2020) Microplastics in take-out food containers. J Hazard Mater 399:122969. https://doi.org/10.1016/j. jhazmat.2020.122969

Endersen L, Coffey A (2020) The use of bacteriophages for food safety. Curr Opin Food Sci 36:1-8. https://doi.org/10.1016/j.cofs.2020.10. 006

Farahy O, Laghfiri M, Bourioug M, Aleya L (2021) Overview of pesticide use in Moroccan apple orchards and its effects on the environment. Curr Opin Environ Sci Heal 19:100223. https://doi.org/10. 1016/j.coesh.2020.10.011

Feng XC, Bao X, Che L, Wu QL (2021) Enhance biological nitrogen and phosphorus removal in wastewater treatment process by adding food waste fermentation liquid as external carbon source. Biochem Eng J 165:107811. https://doi.org/10.1016/j.bej.2020.107811

Fernandes M, Salvador A, Alves MM, Vicente AA (2020) Factors affecting polyhydroxyalkanoates biodegradation in soil. Polym Degrad Stab 182:109408

Frederiksen M, Vorkamp K, Thomsen M, Knudsen LE (2009) Human internal and external exposure to PBDEs - a review of levels and sources. Int J Hyg Environ Health 212:109-134

Friedman M (2003) Chemistry, biochemistry, and safety of acrylamide. A review. J Agric Food Chem 51:4504-4526

Frische T, Matezki S, Wogram J (2014) Environmental risk assessment of pesticide mixtures under regulation 1107/2009/EC: a regulatory review by the German Federal Environment Agency (UBA). J fur Verbraucherschutz und Leb 9:377-389. https://doi.org/10.1007/ s00003-014-0916-6

Fung F, Wang HS, Menon S (2018) Food safety in the 21st century. Biom J 41:88-95. https://doi.org/10.1016/j.bj.2018.03.003

Gallo M, Ferrara L, Calogero A et al (2020) Relationships between food and diseases: what to know to ensure food safety. Food Res Int 137: 109414. https://doi.org/10.1016/j.foodres.2020.109414

Gandhi M, Chikindas ML (2007) Listeria: a foodborne pathogen that knows how to survive. Int J Food Microbiol 113:1-15

Geueke B, Groh K, Muncke J (2018) Food packaging in the circular economy: overview of chemical safety aspects for commonly used materials. J Clean Prod 193:491-505. https://doi.org/10.1016/j. jclepro.2018.05.005

Gholamhosseini A, Shiry N, Soltanian S, Banaee M (2021) Bioaccumulation of metals in marine fish species captured from the northern shores of the Gulf of Oman, Iran. Reg Stud Mar Sci 41:101599. https://doi.org/10.1016/j.rsma.2020.101599

Griesche C, Baeumner AJ (2020) Biosensors to support sustainable agriculture and food safety. TrAC - Trends Anal Chem 128:115906. https://doi.org/10.1016/j.trac.2020.115906

Guan Y, Xiao Y, Wang F et al (2021) Health impacts attributable to ambient PM2.5 and ozone pollution in major Chinese cities at seasonal-level. J Clean. Prod 311:127510. https://doi.org/10.1016/j. jclepro.2021.127510

Haghighi H, Licciardello F, Fava P et al (2020) Recent advances on chitosan-based films for sustainable food packaging applications. Food Packag Shelf Life 26:100551

Hahladakis JN, Velis CA, Weber R et al (2018) An overview of chemical additives present in plastics: migration, release, fate and environmental impact during their use, disposal and recycling. J Hazard Mater 344:179-199

Halagarda M, Kędzior W, Pyrzyńska E (2018) Nutritional value and potential chemical food safety hazards of selected Polish sausages as influenced by their traditionality. Meat Sci 139:25-34. https://doi. org/10.1016/j.meatsci.2018.01.006

Hao X, Zhang X, Cao X et al (2018) Characterization and carcinogenic risk assessment of polycyclic aromatic and nitro-polycyclic aromatic hydrocarbons in exhaust emission from gasoline passenger cars using on-road measurements in Beijing, China. Sci Total Environ 645:347-355. https://doi.org/10.1016/j.scitotenv.2018.07.113

He H-J, Sun D-W (2015) Hyperspectral imaging technology for rapid detection of various microbial contaminants in agricultural and food products. Trends Food Sci Technol 46:99-109. https://doi.org/10. 1016/j.tifs.2015.08.001

He JF, Lv XG, Lin QB et al (2019a) Migration of metal elements from polylactic acid dinner plate into acidic food simulant and its safety evaluation. Food Packag Shelf Life 22:100381. https://doi.org/10. 1016/j.fps1.2019.100381

He LY, Ying GG, Liu YS et al (2016) Discharge of swine wastes risks water quality and food safety: antibiotics and antibiotic resistance genes from swine sources to the receiving environments. Environ Int 92-93:210-219. https://doi.org/10.1016/j.envint.2016.03.023

He M, Shen H, Li Z et al (2019b) Ten-year regional monitoring of soilrice grain contamination by heavy metals with implications for target remediation and food safety. Environ Pollut 244:431-439. https://doi.org/10.1016/j.envpol.2018.10.070

Hong HA, Le HD, Cutting SM (2005) The use of bacterial spore formers as probiotics. FEMS Microbiol Rev 29:813-835

Huang W, Zhao C, Zhong H et al (2019) Bisphenol S induced epigenetic and transcriptional changes in human breast cancer cell line MCF-7. Environ Pollut 246:697-703. https://doi.org/10.1016/j.envpol.2018. 12.084

Humphrey T, O’Brien S, Madsen M (2007) Campylobacters as zoonotic pathogens: a food production perspective. Int J Food Microbiol 117: 237-257 
Imathiu S (2020) Benefits and food safety concerns associated with consumption of edible insects. NFS J 18:1-11. https://doi.org/10.1016/j. nfs.2019.11.002

Järup L, Åkesson A (2009) Current status of cadmium as an environmental health problem. Toxicol Appl Pharmacol 238:201-208

Jiang S, Hagesteijn KFL, Ni J, Ladewig BP (2018) A scientometric study of the research on ion exchange membranes. RSC Adv 8:2403624048. https://doi.org/10.1039/c8ra04686g

Jiang S, Sun H, Wang H et al (2021) A comprehensive review on the synthesis and applications of ion exchange membranes. Chemosphere 282:130817. https://doi.org/10.1016/j.chemosphere. 2021.130817

Kamali M, Jahaninafard D, Mostafaie A et al (2020) Scientometric analysis and scientific trends on biochar application as soil amendment. Chem Eng J 395:125128. https://doi.org/10.1016/j.cej.2020.125128

Kang S, Ravensdale JT, Coorey R et al (2020) Bacterial community analysis using $16 \mathrm{~S}$ rRNA amplicon sequencing in the boning room of Australian beef export abattoirs. Int J Food Microbiol 332: 108779. https://doi.org/10.1016/j.ijfoodmicro.2020.108779

Kasonga TK, Coetzee MAA, Kamika I et al (2021) Endocrine-disruptive chemicals as contaminants of emerging concern in wastewater and surface water: a review. J Environ Manag 277:111485. https://doi. org/10.1016/j.jenvman.2020.111485

Kathariou S (2002) Listeria monocytogenes virulence and pathogenicity, a food safety perspective. J Food Prot 65:1811-1829

Kaushal S, Priyadarshi N, Pinnaka AK et al (2019) Glycoconjugates coated gold nanorods based novel biosensor for optical detection and photothermal ablation of food borne bacteria. Sensors Actuators B Chem 289:207-215. https://doi.org/10.1016/j.snb. 2019.03.096

Kawacka I, Olejnik-Schmidt A, Schmidt M, Sip A (2020) Effectiveness of phage-based inhibition of listeria monocytogenes in food products and food processing environments. Microorganisms 8:1-20

Kenawy ER, Worley SD, Broughton R (2007) The chemistry and applications of antimicrobial polymers: a state-of-the-art review. Biomacromolecules 8:1359-1384

Khalaj M, Kamali M, Costa MEV, Capela I (2020) Green synthesis of nanomaterials - a scientometric assessment. J Clean Prod 267: 122036. https://doi.org/10.1016/j.jclepro.2020.122036

Khalid S, Yu L, Feng M et al (2018) Development and characterization of biodegradable antimicrobial packaging films based on polycaprolactone, starch and pomegranate rind hybrids. Food Packag Shelf Life 18:71-79. https://doi.org/10.1016/j.fpsl.2018.08. 008

Koch N, Islam NF, Sonowal S et al (2021) Environmental antibiotics and resistance genes as emerging contaminants: methods of detection and bioremediation. Curr Res Microb Sci 2:100027. https://doi. org/10.1016/j.crmicr.2021.100027

Koopmans M, Duizer E (2004) Foodborne viruses: an emerging problem. Int J Food Microbiol 90:23-41. https://doi.org/10.1016/S01681605(03)00169-7

Korkmaz C, Ay Ö, Ersoysal Y et al (2019) Heavy metal levels in muscle tissues of some fish species caught from north-east Mediterranean: evaluation of their effects on human health. J Food Compos Anal 81:1-9. https://doi.org/10.1016/j.jfca.2019.04.005

Kumar M, Xiong X, He M et al (2020) Microplastics as pollutants in agricultural soils. Environ Pollut 265:114980. https://doi.org/10. 1016/j.envpol.2020.114980

Lacey LA, Frutos R, Kaya HK, Vail P (2001) Insect pathogens as biological control agents: do they have a future? Biol Control 21:230 248. https://doi.org/10.1006/bcon.2001.0938

Lang M, Yu X, Liu J et al (2020) Fenton aging significantly affects the heavy metal adsorption capacity of polystyrene microplastics. Sci Total Environ 722:137762. https://doi.org/10.1016/j.scitotenv.2020. 137762
Lee CBTL, Wu TY (2021) A review on solvent systems for furfural production from lignocellulosic biomass. Renew Sust Energ Rev 137:110172. https://doi.org/10.1016/j.rser.2020.110172

Lee CBTL, Wu TY, Cheng CK et al (2021) Nonsevere furfural production using ultrasonicated oil palm fronds and aqueous choline chloride-oxalic acid. Ind Crop Prod 166:113397. https://doi.org/10. 1016/j.indcrop.2021.113397

Li J, Song Y, Cai Y (2020a) Focus topics on microplastics in soil: analytical methods, occurrence, transport, and ecological risks. Environ Pollut 257:113570. https://doi.org/10.1016/j.envpol.2019.113570

Li JF, Huang YF, Ding Y et al (2010) Shell-isolated nanoparticle-enhanced Raman spectroscopy. Nature 464:392-395. https://doi.org/ 10.1038/nature08907

Li S, Zhao S, Yan S et al (2019) Food processing wastewater purification by microalgae cultivation associated with high value-added compounds production —a review. Chin J Chem Eng 27:2845-2856. https://doi.org/10.1016/j.cjche.2019.03.028

Li W, Wufuer R, Duo J et al (2020b) Microplastics in agricultural soils: extraction and characterization after different periods of polythene film mulching in an arid region. Sci Total Environ 749:141420. https://doi.org/10.1016/j.scitotenv.2020.141420

Li Y, Jiang S, Wang T et al (2018) Research on biochar via a comprehensive scientometric approach. RSC Adv 8:28700-28709. https:// doi.org/10.1039/c8ra05689g

Li Y, Yao J, Nie P et al (2020c) An effective method for the rapid detection of microplastics in soil. Chemosphere 276:128696. https://doi.org/10.1016/j.chemosphere.2020.128696

Likotrafiti E, Oniciuc E, Prieto M et al (2018) Risk assessment of antimicrobial resistance along the food chain through cultureindependent methodologies. EFSA J 16:e160811. https://doi.org/ 10.2903/j.efsa.2018.e160811

Lin Q, Chousalkar KK, McWhorter AR, Khan S (2021) Salmonella Hessarek: an emerging food borne pathogen and its role in egg safety. Food Control 125:107996. https://doi.org/10.1016/j. foodcont.2021.107996

Liu G, Agostinho F, Duan H et al (2020a) Environmental impacts characterization of packaging waste generated by urban food delivery services. A big-data analysis in Jing-Jin-Ji region (China). Waste Manag 117:157-169. https://doi.org/10.1016/j.wasman.2020.07. 028

Liu P, Qi S, Li D, Ravenscroft N (2021) Promoting agricultural innovation as a means of improving China's rural environment. J Environ Manag 280:111675. https://doi.org/10.1016/j.jenvman.2020. 111675

Liu X, Sun T, Feng Q, Zhang D (2020b) Dynamic environmental regulation threshold effect of technical progress on China's environmental pollution. J Clean Prod 272:122780. https://doi.org/10.1016/j. jclepro.2020.122780

Lu Y, Song S, Wang R et al (2015) Impacts of soil and water pollution on food safety and health risks in China. Environ Int 77:5-15. https:// doi.org/10.1016/j.envint.2014.12.010

Luo Q, Hua LZ, Yin H et al (2018) Migration and potential risk of trace phthalates in bottled water: a global situation. Water Res 147:362372

Majdinasab M, Daneshi M, Louis Marty J (2021) Recent developments in non-enzymatic (bio)sensors for detection of pesticide residues: focusing on antibody, aptamer and molecularly imprinted polymer. Talanta 232:122397. https://doi.org/10.1016/j.talanta.2021.122397

Majdinasab M, Hayat A, Marty JL (2018) Aptamer-based assays and aptasensors for detection of pathogenic bacteria in food samples. TrAC Trends Anal Chem 107:60-77. https://doi.org/10.1016/j. trac.2018.07.016

Majdinasab M, Mishra RK, Tang X, Marty JL (2020) Detection of antibiotics in food: new achievements in the development of biosensors. TrAC - Trends Anal Chem 127:115883. https://doi.org/10.1016/j. trac. 2020.115883 
Majdinasab M, Mitsubayashi K, Marty JL (2019) Optical and electrochemical sensors and biosensors for the detection of quinolones. Trends Biotechnol 37:898-915. https://doi.org/10.1016/j.tibtech. 2019.01.004

Mankar AR, Pandey A, Modak A, Pant KK (2021) Pretreatment of lignocellulosic biomass: a review on recent advances. Bioresour Technol 334:125235. https://doi.org/10.1016/j.biortech.2021. 125235

Medina S, Pereira JA, Silva P et al (2019) Food fingerprints - a valuable tool to monitor food authenticity and safety. Food Chem 278:144 162. https://doi.org/10.1016/j.foodchem.2018.11.046

Menzel C (2020) Improvement of starch films for food packaging through a three-principle approach: antioxidants, cross-linking and reinforcement. Carbohydr Polym 250. https://doi.org/10.1016/j. carbpol.2020.116828

Mohamad N, Mazlan MM, Tawakkal ISMA et al (2020) Development of active agents filled polylactic acid films for food packaging application. Int J Biol Macromol 163:1451-1457. https://doi.org/10.1016/j. ijbiomac.2020.07.209

Mohd Ali M, Hashim N, Aziz SA, Lasekan O (2020) Emerging nondestructive thermal imaging technique coupled with chemometrics on quality and safety inspection in food and agriculture. Trends Food Sci Technol 105:176-185. https://doi.org/10.1016/j.tifs.2020. 09.003

More S, Bampidis V, Benford D et al (2020) Evaluation of existing guidelines for their adequacy for the microbial characterisation and environmental risk assessment of microorganisms obtained through synthetic biology. EFSA J 18:e6263. https://doi.org/10.2903/j.efsa. 2020.6263

Motelica L, Ficai D, Ficai A et al (2020) Innovative antimicrobial chito$\mathrm{san} / \mathrm{ZnO} / \mathrm{Ag} \mathrm{NPs} /$ citronella essential oil nanocomposite - potential coating for grapes. Foods 9:1801. https://doi.org/10.3390/ foods 9121801

Mugwagwa LR, Chimphango AFA (2020) Enhancing the functional properties of acetylated hemicellulose films for active food packaging using acetylated nanocellulose reinforcement and polycaprolactone coating. Food Packag Shelf Life 24:100481. https://doi.org/10.1016/j.fpsl.2020.100481

Mulakkal MC, Castillo Castillo A, Taylor AC et al (2021) Advancing mechanical recycling of multilayer plastics through finite element modelling and environmental policy. Resour Conserv Recycl 166: 105371. https://doi.org/10.1016/j.resconrec.2020.105371

Nagajyoti PC, Lee KD, Sreekanth TVM (2010) Heavy metals, occurrence and toxicity for plants: a review. Environ Chem Lett 8:199216

Nelis JLD, Tsagkaris AS, Dillon MJ et al (2020) Smartphone-based optical assays in the food safety field. TrAC - Trends Anal Chem 129: 115934. https://doi.org/10.1016/j.trac.2020.115934

Nešić A, Gordić M, Davidović S et al (2018) Pectin-based nanocomposite aerogels for potential insulated food packaging application. Carbohydr Polym 195:128-135. https://doi.org/10.1016/j.carbpol. 2018.04.076

Newell DG, Koopmans M, Verhoef L et al (2010) Food-borne diseases the challenges of 20years ago still persist while new ones continue to emerge. Int J Food Microbiol 139:S3-S15. https://doi.org/10.1016/j. ijfoodmicro.2010.01.021

Ni J, Steinberger-Wilckens R, Jiang S et al (2021) Novel study on microbial fuel cells via a comprehensive bibliometric and dynamic approach. Rev Environ Health. https://doi.org/10.1515/reveh-20200123

Ong VZ, Wu TY (2020) An application of ultrasonication in lignocellulosic biomass valorisation into bio-energy and bio-based products. Renew Sust Energ Rev 132:109924. https://doi.org/10.1016/j.rser. 2020.109924

Osorio J, Aznar M, Nerín C (2019) Identification of key odorant compounds in starch-based polymers intended for food contact materials. Food Chem 285:39-45. https://doi.org/10.1016/j. foodchem.2019.01.157

Othman SH (2014) Bio-nanocomposite materials for food packaging applications: types of biopolymer and nano-sized filler. Agric Agric Sci Procedia 2:296-303. https://doi.org/10.1016/j.aaspro.2014.11. 042

Ouyang Q, Wang L, Ahmad W et al (2021) A highly sensitive detection of carbendazim pesticide in food based on the upconversion- $\mathrm{MnO} 2$ luminescent resonance energy transfer biosensor. Food Chem 349: 129157. https://doi.org/10.1016/j.foodchem.2021.129157

Pan C, Chen H, Lin Q et al (2020) Evaluation of the SERS-based strategy in fast and on-site food safety inspection: qualitative and quantitative analysis of trace unexpected herbicide in complicated herbicide matrix. J Raman Spectrosc. https://doi.org/10.1002/jrs.6026

Patrício Silva AL, Prata JC, Walker TR et al (2021) Increased plastic pollution due to COVID-19 pandemic: challenges and recommendations. Chem Eng J 405:126683. https://doi.org/10.1016/j.cej. 2020.126683

Pattanayaiying R, Sane A, Photjanataree P, Cutter CN (2019) Thermoplastic starch/polybutylene adipate terephthalate film coated with gelatin containing nisin $\mathrm{Z}$ and lauric arginate for control of foodborne pathogens associated with chilled and frozen seafood. Int J Food Microbiol 290:59-67. https://doi.org/10.1016/j. ijfoodmicro.2018.09.015

Pauk V, Krejčí M, Lemr K (2021) Unified chromatography - mass spectrometry as a versatile tool for determination of food dyes. Anal Chim Acta 1157:338401. https://doi.org/10.1016/j.aca.2021. 338401

Pérez-Arauz AO, Aguilar-Rabiela AE, Vargas-Torres A et al (2019) Production and characterization of biodegradable films of a novel polyhydroxyalkanoate (PHA) synthesized from peanut oil. Food Packag Shelf Life 20:100297. https://doi.org/10.1016/j.fpsl.2019. 01.001

Pilevar Z, Bahrami A, Beikzadeh S et al (2019) Migration of styrene monomer from polystyrene packaging materials into foods: characterization and safety evaluation. Trends Food Sci Technol 91:248261

Pires SM, Duarte AS, Hald T (2018) Source attribution and risk assessment of antimicrobial resistance. Microbiol Spectr 6. https://doi.org/ 10.1128/microbiolspec.arba-0027-2017

Poyatos-Racionero E, Ros-Lis JV, Vivancos JL, Martínez-Máñez R (2018) Recent advances on intelligent packaging as tools to reduce food waste. J Clean Prod 172:3398-3409. https://doi.org/10.1016/j. jclepro.2017.11.075

Praveena SM, Cheema MS, Guo H-R (2019) Non-nutritive artificial sweeteners as an emerging contaminant in environment: a global review and risks perspectives. Ecotoxicol Environ Saf 170:699 707. https://doi.org/10.1016/j.ecoenv.2018.12.048

Primpke S, Christiansen SH, Cowger W et al (2020) Critical assessment of analytical methods for the harmonized and cost-efficient analysis of microplastics. Appl Spectrosc 74:1012-1047. https://doi.org/10. $1177 / 0003702820921465$

Priyadarshi R, Rhim JW (2020) Chitosan-based biodegradable functional films for food packaging applications. Innov Food Sci Emerg Technol 62:102346

Purwiyanto AIS, Suteja Y, Trisno et al (2020) Concentration and adsorption of $\mathrm{Pb}$ and $\mathrm{Cu}$ in microplastics: case study in aquatic environment. Mar Pollut Bull 158:111380. https://doi.org/10.1016/j. marpolbul.2020.111380

Qi J, Fan X-X, Deng D-M et al (2020) Progress in rapid detection techniques using paper-based platforms for food safety. Chin J Anal Chem 48:1616-1624. https://doi.org/10.1016/S1872-2040(20) 60064-0

Qin G, Niu Z, Yu J et al (2021) Soil heavy metal pollution and food safety in China: effects, sources and removing technology. Chemosphere 267:129205. https://doi.org/10.1016/j.chemosphere.2020.129205 
Qin J, Kim MS, Chao K et al (2017) Subsurface inspection of food safety and quality using line-scan spatially offset Raman spectroscopy technique. Food Control 75:246-254. https://doi.org/10.1016/j. foodcont.2016.12.012

Rajeswari A, Christy EJS, Swathi E, Pius A (2020) Fabrication of improved cellulose acetate-based biodegradable films for food packaging applications. Environ Chem Ecotoxicol 2:107-114. https:// doi.org/10.1016/j.enceco.2020.07.003

Rajeswari A, Jackcina Stobel Christy E, Ida Celine Mary G et al (2019) Cellulose acetate based biopolymeric mixed matrix membranes with various nanoparticles for environmental remediation-a comparative study. J Environ Chem Eng 7:103278. https://doi.org/10.1016/j. jece. 2019.103278

Rajmohan KVS, Ramya C, Raja Viswanathan M, Varjani S (2019) Plastic pollutants: effective waste management for pollution control and abatement. Curr Opin Environ Sci Heal 12:72-84. https://doi. org/10.1016/j.coesh.2019.08.006

Riaz A, Lagnika C, Luo H et al (2020) Effect of Chinese chives (Allium tuberosum) addition to carboxymethyl cellulose based food packaging films. Carbohydr Polym 235:115944. https://doi.org/10.1016/j. carbpol.2020.115944

Risyon NP, Othman SH, Basha RK, Talib RA (2020) Characterization of polylactic acid/halloysite nanotubes bionanocomposite films for food packaging. Food Packag Shelf Life 23:100450. https://doi. org/10.1016/j.fpsl.2019.100450

Rotariu L, Lagarde F, Jaffrezic-Renault N, Bala C (2016) Electrochemical biosensors for fast detection of food contaminants - trends and perspective. TrAC - Trends Anal Chem 79:80-87. https://doi.org/10.1016/j.trac.2015.12.017

Safiur Rahman M, Solaiman Hossain M, Ahmed MK et al (2019) Assessment of heavy metals contamination in selected tropical marine fish species in Bangladesh and their impact on human health. Environ Nanotechnol Monit Manag 11:100210. https://doi.org/10. 1016/j.enmm.2019.100210

Sagbara G, Zabbey N, Sam K, Nwipie GN (2020) Heavy metal concentration in soil and maize (Zea mays L.) in partially reclaimed refuse dumpsite 'borrow-pit' in Port Harcourt, Nigeria. Environ Technol Innov 18:100745. https://doi.org/10.1016/j.eti.2020.100745

Saha N, Mollah MZI, Alam MF, Safiur Rahman M (2016) Seasonal investigation of heavy metals in marine fishes captured from the Bay of Bengal and the implications for human health risk assessment. Food Control 70:110-118. https://doi.org/10.1016/j.foodcont. 2016.05.040

Sangroniz A, Sangroniz L, Aranburu N et al (2018) Blends of biodegradable poly(butylene adipate-co-terephthalate) with poly(hydroxi amino ether) for packaging applications: miscibility, rheology and transport properties. Eur Polym J 105:348-358. https://doi.org/10.1016/j. eurpolymj.2018.06.016

Santana Oliveira I, da Silva Junior AG, de Andrade CAS, Lima Oliveira MD (2019) Biosensors for early detection of fungi spoilage and toxigenic and mycotoxins in food. Curr Opin Food Sci 29:64-79. https://doi.org/10.1016/j.cofs.2019.08.004

Saraiva Rodrigues SC, da Silva AS, de Carvalho LH et al (2020) Morphological, structural, thermal properties of a native starch obtained from babassu mesocarp for food packaging application. J Mater Res Technol 9:15670-15678. https://doi.org/10.1016/j.jmrt. 2020.11.030

Sarker A, Deepo DM, Nandi R et al (2020) A review of microplastics pollution in the soil and terrestrial ecosystems: a global and Bangladesh perspective. Sci Total Environ 733:139296. https:// doi.org/10.1016/j.scitotenv.2020.139296

Scaria J, Gopinath A, Nidheesh PV (2021) A versatile strategy to eliminate emerging contaminants from the aqueous environment: heterogeneous Fenton process. J Clean Prod 278:124014. https://doi.org/ 10.1016/j.jclepro.2020.124014
Shahid S, Razzaq S, Farooq R, Nazli ZIH (2020) Polyhydroxyalkanoates: next generation natural biomolecules and a solution for the world's future economy. Int J Biol Macromol 166:297-321

Shen J, Zhao Q, Cheng Z et al (2020) Insights into source origins and formation mechanisms of nitrate during winter haze episodes in the Yangtze River Delta. Sci Total Environ 741:140187. https://doi.org/ 10.1016/j.scitotenv.2020.140187

Shen X, Hao J, Kong L et al (2021a) Variation characteristics of fine particulate matter and its components in diesel vehicle emission plumes. J Environ Sci 107:138-149. https://doi.org/10.1016/j.jes. 2021.01.034

Shen X, Shi Y, Kong L et al (2021b) Particle number emissions from light-duty gasoline vehicles in Beijing, China. Sci Total Environ 773:145663. https://doi.org/10.1016/j.scitotenv.2021.145663

Sicherer SH, Sampson HA (2014) Food allergy: epidemiology, pathogenesis, diagnosis, and treatment. J Allergy Clin Immunol 133:291307

Silveira RF, Roque-Borda CA, Vicente EF (2021) Antimicrobial peptides as a feed additive alternative to animal production, food safety and public health implications: an overview. Anim Nutr. https://doi.org/ 10.1016/j.aninu.2021.01.004

Silvestre C, Duraccio D, Cimmino S (2011) Food packaging based on polymer nanomaterials. Prog Polym Sci 36:1766-1782

Singh H, Bhardwaj SK, Khatri M et al (2020a) UVC radiation for food safety: an emerging technology for the microbial disinfection of food products. Chem Eng J 417:128084. https://doi.org/10.1016/j. cej.2020.128084

Singh S, Dhanjal DS, Sonali et al (2020b) An insight in bacteriophage based biosensors with focus on their detection methods and recent advancements. Environ Technol Innov 20:101081. https://doi.org/ 10.1016/j.eti.2020.101081

Song Y, Yang T, Li Z et al (2020) Research on the direct and indirect effects of environmental regulation on environmental pollution: empirical evidence from 253 prefecture-level cities in China. J Clean Prod 269:122425. https://doi.org/10.1016/j.jclepro.2020.122425

Stoica M, Marian Antohi V, Laura Zlati M, Stoica D (2020) The financial impact of replacing plastic packaging by biodegradable biopolymers - a smart solution for the food industry. J Clean Prod 277:124013. https://doi.org/10.1016/j.jclepro.2020.124013

Su YC, Liu C (2007) Vibrio parahaemolyticus: a concern of seafood safety. Food Microbiol 24:549-558

Suhani I, Sahab S, Srivastava V, Singh RP (2021) Impact of cadmium pollution on food safety and human health. Curr Opin Toxicol 27:17. https://doi.org/10.1016/j.cotox.2021.04.004

Suman M, Cavanna D, Sammarco G et al (2021) Fighting food frauds exploiting chromatography-mass spectrometry technologies: scenario comparison between solutions in scientific literature and real approaches in place in industrial facilities. TrAC Trends Anal Chem 142:116305. https://doi.org/10.1016/j.trac.2021.116305

Sun F, DAI Y, Yu X (2017) Air pollution, food production and food security: a review from the perspective of food system. J Integr Agric 16:2945-2962

Swaroop C, Shukla M (2019) Development of blown polylactic acid$\mathrm{MgO}$ nanocomposite films for food packaging. Compos Part A Appl Sci Manuf 124:105482. https://doi.org/10.1016/j. compositesa.2019.105482

Swaroop C, Shukla M (2018) Nano-magnesium oxide reinforced polylactic acid biofilms for food packaging applications. Int J Biol Macromol 113:729-736. https://doi.org/10.1016/j.ijbiomac.2018. 02.156

Titchou FE, Zazou H, Afanga H et al (2021) Removal of persistent organic pollutants (POPs) from water and wastewater by adsorption and electrocoagulation process. Groundw Sustain Dev 13:100575. https://doi.org/10.1016/j.gsd.2021.100575

Tompkin RB (2002) Control of Listeria monocytogenes in the foodprocessing environment. J Food Prot 65:709-725 
Tóth G, Hermann T, Da Silva MR, Montanarella L (2016) Heavy metals in agricultural soils of the European Union with implications for food safety. Environ Int 88:299-309. https://doi.org/10.1016/j. envint.2015.12.017

Tsai MY, Lin CF, Yang WC et al (2019) Health risk assessment of banned veterinary drugs and quinolone residues in shrimp through liquid chromatography-tandem mass spectrometry. Appl Sci 9: 2463. https://doi.org/10.3390/app9122463

Van Boxstael S, Habib I, Jacxsens L et al (2013) Food safety issues in fresh produce: bacterial pathogens, viruses and pesticide residues indicated as major concerns by stakeholders in the fresh produce chain. Food Control 32:190-197. https://doi.org/10.1016/j. foodcont.2012.11.038

Van Cauwenberghe L, Janssen CR (2014) Microplastics in bivalves cultured for human consumption. Environ Pollut 193:65-70. https:// doi.org/10.1016/j.envpol.2014.06.010

van Wesenbeeck CFA, Keyzer MA, van Veen WCM, Qiu H (2021) Can China's overuse of fertilizer be reduced without threatening food security and farm incomes? Agric Syst 190:103093. https://doi. org/10.1016/j.agsy.2021.103093

Velusamy A, Satheesh Kumar P, Ram A, Chinnadurai S (2014) Bioaccumulation of heavy metals in commercially important marine fishes from Mumbai Harbor, India. Mar Pollut Bull 81:218-224. https://doi.org/10.1016/j.marpolbul.2014.01.049

Vilarinho F, Sendón R, van der Kellen A et al (2019) Bisphenol A in food as a result of its migration from food packaging. Trends Food Sci Technol 91:33-65

Vipham JL, Amenu K, Alonso S et al (2020) No food security without food safety: lessons from livestock related research. Glob Food Sec 26:100382. https://doi.org/10.1016/j.gfs.2020.100382

Vitale G, Mosna D, Bottani E et al (2018) Environmental impact of a new industrial process for the recovery and valorisation of packaging materials derived from packaged food waste. Sustain Prod Consum 14:105-121. https://doi.org/10.1016/j.spc.2018.02.001

Wainaina S, Horváth IS, Taherzadeh MJ (2018) Biochemicals from food waste and recalcitrant biomass via syngas fermentation: a review. Bioresour Technol 248:113-121. https://doi.org/10.1016/j.biortech. 2017.06.075

Wang C, Xiao R, Wang S et al (2019a) Magnetic quantum dot based lateral flow assay biosensor for multiplex and sensitive detection of protein toxins in food samples. Biosens Bioelectron 146:111754. https://doi.org/10.1016/j.bios.2019.111754

Wang L, Luo D, Liu X et al (2021a) Effects of PM2.5 exposure on reproductive system and its mechanisms. Chemosphere 264: 128436. https://doi.org/10.1016/j.chemosphere.2020.128436

Wang P, Chen H, Kopittke PM, Zhao F-J (2019b) Cadmium contamination in agricultural soils of China and the impact on food safety. Environ Pollut 249:1038-1048. https://doi.org/10.1016/j.envpol. 2019.03.063

Wang R, Han X, Pang H et al (2021b) Illuminating a time-response mechanism in mice liver after PM2.5 exposure using metabolomics analysis. Sci Total Environ 767:144485. https://doi.org/10.1016/j. scitotenv.2020.144485

Wang W, Leung AOW, Chu LH, Wong MH (2018) Phthalates contamination in China: status, trends and human exposure-with an emphasis on oral intake. Environ Pollut 238:771-782

Wang Y, Wang X, Li Y et al (2021c) Effects of exposure of polyethylene microplastics to air, water and soil on their adsorption behaviors for copper and tetracycline. Chem Eng J 404:126412. https://doi.org/10. 1016/j.cej.2020.126412

Weidemaier K, Carruthers E, Curry A et al (2015) Real-time pathogen monitoring during enrichment: a novel nanotechnology-based approach to food safety testing. Int J Food Microbiol 198:19-27. https://doi.org/10.1016/j.ijfoodmicro.2014.12.018
Weir A, Westerhoff P, Fabricius L et al (2012) Titanium dioxide nanoparticles in food and personal care products. Environ Sci Technol 46:2242-2250. https://doi.org/10.1021/es204168d

Weng X, Neethirajan S (2017) Ensuring food safety: quality monitoring using microfluidics. Trends Food Sci Technol 65:10-22. https://doi. org/10.1016/j.tifs.2017.04.015

Wohner B, Gabriel VH, Krenn B et al (2020) Environmental and economic assessment of food-packaging systems with a focus on food waste. Case study on tomato ketchup. Sci Total Environ 738: 139846. https://doi.org/10.1016/j.scitotenv.2020.139846

Woraprayote W, Pumpuang L, Tosukhowong A et al (2018) Antimicrobial biodegradable food packaging impregnated with Bacteriocin 7293 for control of pathogenic bacteria in pangasius fish fillets. LWT Food Sci Technol 89:427-433. https://doi.org/10.1016/ j.lwt.2017.10.026

Wu B, Shen X, Cao X et al (2016) Characterization of the chemical composition of PM2.5 emitted from on-road China III and China IV diesel trucks in Beijing, China. Sci Total Environ 551-552:579 589. https://doi.org/10.1016/j.scitotenv.2016.02.048

Wu B, Xuan K, Zhang X et al (2021a) Mass absorption cross-section of black carbon from residential biofuel stoves and diesel trucks based on real-world measurements. Sci Total Environ 784:147225. https:// doi.org/10.1016/j.scitotenv.2021.147225

Wu M, Yang C, Du C, Liu H (2020a) Microplastics in waters and soils: occurrence, analytical methods and ecotoxicological effects. Ecotoxicol Environ Saf 202:110910. https://doi.org/10.1016/j. ecoenv.2020.110910

Wu MY-C, Hsu M-Y, Chen S-J et al (2017) Point-of-care detection devices for food safety monitoring: proactive disease prevention. Trends Biotechnol 35:288-300. https://doi.org/10.1016/j.tibtech. 2016.12.005

Wu ST, Hammons SR, Silver R et al (2020b) Retail deli managers and associates have better food safety culture in stores with lower Listeria monocytogenes contamination. Food Control 110:106983. https://doi.org/10.1016/j.foodcont.2019.106983

$\mathrm{Wu} \mathrm{Z,} \mathrm{Pu} \mathrm{H,} \mathrm{Sun} \mathrm{D-W} \mathrm{(2021b)} \mathrm{Fingerprinting} \mathrm{and} \mathrm{tagging} \mathrm{detection} \mathrm{of}$ mycotoxins in agri-food products by surface-enhanced Raman spectroscopy: principles and recent applications. Trends Food Sci Technol 110:393-404. https://doi.org/10.1016/j.tifs.2021.02.013

Xie J, Hung YC (2018) UV-A activated TiO2 embedded biodegradable polymer film for antimicrobial food packaging application. Lwt 96: 307-314. https://doi.org/10.1016/j.lwt.2018.05.050

Yao L, Ouyang L, Lv J et al (2021) Rapid and sensitive SERS detection of food contaminants by using nano-Ag aggregates with controllable hydrophobicity. Microchem J 166:106221. https://doi.org/10.1016/ j.microc.2021.106221

Yao X, Wang K, Zhang S et al (2020) Degradation of the mixture of ethyl formate, propionic aldehyde, and acetone by Aeromonas salmonicida: a novel microorganism screened from biomass generated in the citric acid fermentation industry. Chemosphere 258: 127320. https://doi.org/10.1016/j.chemosphere.2020.127320

Yasotha A, Dabadé DS, Singh VP, Sivakumar T (2020) Risk assessment of heavy metals in milk from cows reared around industrial areas in India. Environ Geochem Health. https://doi.org/10.1007/s10653020-00758-1

Ye FF, Yang LH, Wang YM, Chen L (2020) An environmental pollution management method based on extended belief rule base and data envelopment analysis under interval uncertainty. Comput Ind Eng 144:106454. https://doi.org/10.1016/j.cie.2020.106454

Ye Y, Guo H, Sun X (2019) Recent progress on cell-based biosensors for analysis of food safety and quality control. Biosens Bioelectron 126 : 389-404. https://doi.org/10.1016/j.bios.2018.10.039

Yu B, Wang X, Dong KF et al (2020a) Heavy metal concentrations in aquatic organisms (fishes, shrimp and crabs) and health risk assessment in China. Mar Pollut Bull 159:111505. https://doi.org/10. 1016/j.marpolbul.2020.111505 
Yu F, Li Y, Huang G et al (2020b) Adsorption behavior of the antibiotic levofloxacin on microplastics in the presence of different heavy metals in an aqueous solution. Chemosphere 260:127650. https:// doi.org/10.1016/j.chemosphere.2020.127650

Zakka WP, Abdul Shukor Lim NH, Chau Khun M (2021) A scientometric review of geopolymer concrete. J Clean Prod 280: 124353. https://doi.org/10.1016/j.jclepro.2020.124353

Zeb A, Liu W, Wu J et al (2021) Knowledge domain and emerging trends in nanoparticles and plants interaction research: a scientometric analysis. NanoImpact 21:100278. https://doi.org/10.1016/j.impact. 2020.100278

Zeng T, Durif F, Robinot E (2021) Can eco-design packaging reduce consumer food waste? an experimental study. Technol Forecast Soc Change 162:120342. https://doi.org/10.1016/j.techfore.2020. 120342

Zhang S, Wang J, Yan P et al (2020) Non-biodegradable microplastics in soils: a brief review and challenge. J Hazard Mater 409:124525. https://doi.org/10.1016/j.jhazmat.2020.124525

Zhang X-N, Guo Q-P, Shen X-X et al (2015) Water quality, agriculture and food safety in China: Current situation, trends, interdependencies, and management. J Integr Agric 14:2365-2379. https:// doi.org/10.1016/S2095-3119(15)61128-5

Zhang X, Wu D, Zhou X et al (2019) Recent progress in the construction of nanozyme-based biosensors and their applications to food safety assay. TrAC - Trends Anal Chem 121:115668. https://doi.org/10. 1016/j.trac.2019.115668

Zhenquan V, Yeong T, Kai K et al (2021) Industrial crops \& products A combined pretreatment with ultrasound-assisted alkaline solution and aqueous deep eutectic solvent for enhancing delignification and enzymatic hydrolysis from oil palm fronds. Ind Crop Prod 160:112974. https://doi.org/10.1016/j.indcrop.2020.112974

Zhou X, Wang J, Li H et al (2021) Microplastic pollution of bottled water in China. J Water Process Eng 40:101884. https://doi.org/10.1016/j. jwpe.2020.101884

Zhou Y, Liu X, Wang J (2019) Characterization of microplastics and the association of heavy metals with microplastics in suburban soil of central China. Sci Total Environ 694:133798. https://doi.org/10. 1016/j.scitotenv.2019.133798

Zhou Y, Wang J, Zou M et al (2020) Microplastics in soils: a review of methods, occurrence, fate, transport, ecological and environmental risks. Sci Total Environ 748:141368. https://doi.org/10.1016/j. scitotenv.2020.141368

Publisher's note Springer Nature remains neutral with regard to jurisdictional claims in published maps and institutional affiliations. 